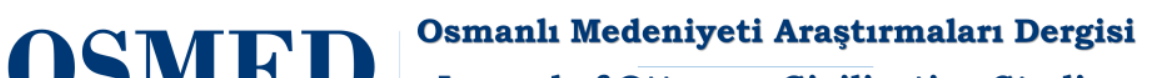 Journal of Ottoman Civilization Studies

\section{Yeşilova Köyü'nün XIX. Yüzyılda Sosyo-Ekonomik Yapısı}

Socio-Economic Structure of the Yeşilova Village in the XIX. Century

\author{
Ahmet Sağlam \\ Doç. Dr. \\ Burdur Mehmet Akif Ersoy Üniversitesi \\ Tarih Bölümü \\ ahmetsaglam352@gmail.com \\ ORCID ID : 0000-0002-9002-529X

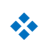

\section{Makale Bilgisi / Article Information} \\ Makale Türü / Article Type : Araştırma Makalesi \\ Geliş Tarihi / Received : 6 Nisan 2021 \\ Kabul Tarihi / Accepted : 20 May1s 2021 \\ Yayın Tarihi / Published : 15 Ekim 2021 \\ DOI Number : 10.21021/osmed.910483
}

\section{Kaynak Gösterme / Citation}

Sağlam, A. “Yeşilova Köyü'nün XIX. Yüzyılda Sosyo-Ekonomik Yapısı". Osmanlı Medeniyeti Araştırmaları Dergisi, 13 (2021): 1-38. 


\title{
Yeşilova Köyü'nün XIX. Yüzyılda Sosyo-Ekonomik Yapısı
}

\author{
Socio-Economic Structure of the Yeșilova Village in the XIX. Century
}

\section{Ahmet Sağlam}

$\ddot{O} z$

Osmanlı nüfus ve temettüat defterleri, yerel tarih çalışmaları yanında birçok bilim dalı için zengin malzeme kaynağıdır. 19. Yüzyılda köy ve kentlerin nüfus bilgileri, etnik ve dini yapıları, sosyoekonomik hayatlarına dair istatistiki bilgiler bu defterlerde kayıtlıdır. Imparatorlukların ulusal devletlere dönüşüm sürecinin yaşandığı bir yüzyıl olması, arşiv kayıtlarını daha da değerli kılmaktadır.

Makalemizde, Kütahya sancağı Simav kazası İ̆diş karyesi nüfus ve temettüat defterleri ışığında günümüz Kütahya-Gediz-Yeşilova Köyü’nün 1840 yılı nüfus defteri ve 1844/45 yılı temettüat defterine göre köy sakinlerinin sosyo-ekonomik hayatlarını ele alacağız. Önceki adı "iğdiş" olan, 1970-Gediz depremi sonrası yeni yerleşim merkezi ile adı "Yeşilova" olan köy tarihine dair 1500'lere değin Osmanlı arşivlerinde kayıtlara ulaşmak ve köy hakkında bilgi sahibi olmak mümkündür. Nüfus ve temettüat defterlerine göre yaklaşık 200 kişilik bir nüfusa sahip olan köy, kuru tarım ve hayvancılığa elverişli toprakların yanı sıra, zengin orman kaynaklarına sahiptir. Bu noktada temettüat defterine göre tarım, hayvancılık ve arıılık temel geçim kaynaklarıdır. Sanayi öncesi toplum yapısını dikkate aldığımızda, özellikle orta Anadolu köylerine kıyasla geçim kaynakları bakımından iyi bir konumda olduğunu söylemek mümkündür.

Anahtar Kelimeler: Osmanlı, nüfus, temettuat, vergi, Yeşilova/İğdiş

\section{Abstract}

Ottoman population and temettüat registers are a rich source of material for local history studies. It gives detailed information about the population information of villages and cities, ethnic and religious structure, socio-conomic life and income records of individuals. These archive records belonging to the 19th century, when the process of transformation of empires into national states began, are also important archive catalogs for many different branches of science.

In our article, we will talk about the population of Gediz Yeşilova Village in 1840 and the socioeconomic life of the village residents in 1844/45 in the light of the population. It is possible to reach records in Ottoman archives up to 1500 s regarding the history of the village. Formerly known as İğdis, the new settlement center after the 1970-Gediz earthquake and the village, whose name is Yeşilova. The village has rich forest resources as well as land suitable for dry farming and animal husbandry. According to the Temettüat registers, agriculture, animal husbandry and beekeeping are among the main sources of income. Considering the preindustrial social structure, the village has a good position in terms of livelihoods, especially compared to the central Anatolian villages.

Keywords: Osmanlı, nüfus, temettuat, population, tax, Yeşilova/lĭgiş 


\section{Giriş}

Osmanlı nüfus ve temettüat defterleri 19. yüzyıl yerel tarih çalışmaları için önemli arşiv kayıtlarıdır. Birçok bilim dalı ${ }^{1}$ için kaynak teşkil eden bu kayıtlar, köy ve mahalle bazında, kişiler ve sahip oldukları servetler hakkında detaylı bilgiler verir. Doğrusu Osmanlı arşiv kayıtları, nitelik ve tür açısından oldukça zengindir. Bu kayıtların muhafazası, geçmişe dair malumat vermesinin yanında gelecek nesillere karşı da sorumluluk anlayışının bir göstergesidir. Nitekim bu kayıtlar, geçmişte Osmanlı idaresinde kalan, günümüzün sayısız devleti ve bu devletlerdeki çok farklı etnik grupların ve toplumların tarihine 1şık tutacak mahiyettedir.

Sosyal ve iktisat tarihi için önemli olan nüfus ve temettüat kayıtlarının içeriği hangi konularda bizlere bilgi verir? Defterlerin kapakları, ilk son sayfalarında yerleşim yeri ve yöneticilere ait kayıtlar, 19. Yüzyıl yerleşim birimleri ve yöneticileri hakkında bilgiler verir. Nüfus defterlerinde; demografik yapı, etnik ve dini yapı, köy ya da mahalle bazında toplumsal yapı, hanelerin çekirdek ya da kalabalık aile yapıları, kişilerin eşkâlleri, fiziki özellikleri, engelli durumları, köyler arasındaki göçler hakkında bilgiler verir. Temettüat defterlerinde, köy ya da mahalle sakinlerinin ekonomik faaliyetleri, gelirleri, servetleri ile ödediği vergiler hakkında açık veriler bulunur. Kişilerin emlak, arazi ve sahibi olduğu hayvanlar tek tek kayıtlıdır. Esnaf ve tüccara dair malumatlar meslekler ve iş kolları hakkında bilgi sahibi olmamızı sağlar. Ziraat yapılan ekili dikili alanlarda yetiştirilen hububat ile bağ, bahçe ve bostan alanlarından elde edilen ürünler kayıtlıdır. Yine vergi yükümlüsüne ait unvan, lakap, meslek, resmi görev, etnik unsur bütün ayrıntılarıyla yer alır. Bu anlamda hane reisinin toplumsal statüsü hakkında bilgi vardır. Kuşkusuz geçim kaynakları yaşam biçimlerini etkileyen önemli bir unsurdur. Özetle, defterler dönemin sosyo-ekonomik tarihine kaynak teşkil eder.

Nüfus defterleri, Sultan II. Mahmut devrinde düzenlenmeye başlamıştır. Sadece erkeklerin kayıt altına alındığı bu sayım ile amaç, zorunlu askerlik hizmetine alınacak asker adaylarının yoklamasıdır. Doğrusu Yeniçeri Ocağı kaldırılmış, yeni bir anlayışla ordu teşkiline gidilmiştir. Yeni orduya asker temini için nüfus defterlerinde müslim ve reaya (gayrimüslim nüfus) ayrı ayrı sayılmış, defterleri de ayrı tutulmuştur. Sancak, kaza ve köyler kaydedilmiştir. Kayıtlarda adı geçen erkeklerin yaşları, eşkâlleri, askerlik durumları, lakapları, mensup oldukları aile ve sülale bilgileri yazılmıştır. ${ }^{2}$

\section{Kaynaklar}

Cumhurbaşkanlığı Osmanlı Arşivleri'nde Yeşilova Köyü nüfus sayımı ve yoklama kayıtlarının bulunduğu defterler vardır. Köy nüfus sayım bilgileri idari olarak bağlı bulunduğu Kütahya sancağına tâbi Simav kazası ve köylerine ait üç ayrı mufassal nüfus sayım defterinde kayıtlıdır. Bu üç ana nüfus defteri dışında "Nüfus Ceride Muhasebesi" adı ile kayıtlı KK.d.06447-163 numaralı nüfus yoklama defteri ile 1247-1287/1831-1870 yılları arasında her yıl doğan-ölen/tevellüd-fevt kayıtlarının tutulduğu defterler vardır. Makalemizde nüfus bilgilerini kullandığımız defter NFS.d.1629 künyeli defterdir. Bu defterde 1256/1840 yılına ait erkek nüfus kayıtları yazılıdır. Adı geçen Ceride Muhasebe defteri 1 Recep 1255/10 Eylül 1839 tarihli olup, bu defterde tevellüdü/doğumu kaydedilen çocuklar,1629 no'lu defterde bir yaşında kayıtlıdır. Bu defterden başka Simav kazasına ait diğer mufassal iki defterin daha önce kaydedildiği

\footnotetext{
1 Temettüat defterlerinin tarihi coğrafya alanında kullanımına dair örnek bir çalışma için bkz. İlker Yiğit, "XIX. Yüzyıl Tarihi Coğrafya Çalışmaları İçin Önemli Bir Kaynak: Temettüat Defterleri", Türk Coğrafya Kurumunun 70. Kuruluş Yılı Anısına: "UKCK-2011" Bildirileri, 7-10 Eylül 2011 İstanbul. Yine çalışma bölgemize dair Gediz merkez ve köylerine ait temettüat defterleri dikkate alınarak, farklı disiplinlerce bütüncül bir bakış açısıyla hazırlanmış iki tez çalışması bu anlamda örnek çalışmalardır. Aloda Kaplan, 19. Yüzyılda Gediz Nahiye'sinin Sosyo-Ekonomik Yapısı", İstanbul Üniversitesi, Sosyal Bilimler Enstitüsü Iktisat Tarihi Anabilim Dalı, İstanbul 2005. Fatıma Rezzan Gürsoy, "XVI-XIX. Yüzyıllarda Gediz'de Toplumsal Hayat”, Uşak Üniversitesi, Sosyal Bilimler Enstitüsü Sosyal Bilimler Anabilim Dalı, Uşak 2011.

2 Enver Ziya Karal, Osmanlı Imparatorluğunda IIk Nüfus Sayımı 1831, T.C Başbakanlık Devlet İstatistik Enstitüsü Yayınları, Ankara 1943 , s. 8-11.
} 
anlaşılır. İlkinin kapağında açık bir biçimde 1247/1831 y1lı yazılı olan NFS.d.01627 künyeli defter, ikincisi ise NFS.d.01628 künyeli 21 Şevval 1249/3 Mart 1834 tarihli olan defterdir. Her üç defterde makale konumuz olan İğdiş/Yeşilova Köyü'ne ait nüfus bilgileri mevcuttur.

NFS.d.01629 künyeli 1840 tarihli mufassal nüfus defterinin 201-203. sayfalarında "Karye-i İğdiş" adı ile köy nüfus bilgileri yer alır. Sadece erkek kişilerin adlarının yer aldığı bu deftere göre köyde 31 hane, 78 erkek nüfus kayıtlıdır. Yine 1845 tarihli temettüat defterinde nüfus mevcudu 87 olarak yer alır. ${ }^{3}$ Kadın nüfus ile beraber toplamda yaklaşık 200 nüfuslu bir köy olduğunu söylemek mümkündür. Nüfus defterinde hanenin en yaşlı erkek üyesi aynı zamanda hane reisi olarak kaydedilmiştir. Aynı evde ikamet eden diğer erkek bireyler hane reisine yakınlığına göre "oğlu", "torunu", "karındaşı", "biraderi" olduğunu belirten ifade ile başlamış, boy, sakal, bıyık türü ile eşkâline atıfta bulunduktan sonra baba adı ile kişi adı birlikte verilmiştir. Son olarak yaşı yazılmıştır. Askerde olanlar için "mansûre' de" ibaresi yer alırken, hanede var ise üvey evlatlar da "rebîbi" ifadesi ile belirtilmiştir. Dikkat çeken bir husus 25 yaş altı olan kişilerin yaş1 açıkça yazılırken, 25 yaş üzeri olanlar beş yaş ara ile yazılmışlardır. Yine kayıtta, her hane ve her nüfus için ayrı ayrı sıra numarası verilmiş, en başından sonuna değin devam eden bir sıra numarası takip edilmiştir. Böylece, en son kişinin sıra numarası aynı zamanda toplam erkek nüfus sayısını vermektedir. Önceki iki deftere göre daha düzenli olduğu görülen bu defterde, daha önceki iki defterde yer alan "misafir" kaydı ile köye sonradan yerleşenler, yine başka yere göç edenleri belirtmek için yazılan "muhacir" kayıtları yer almamıştır.

Makalemizin diğer önemli kaynağı köy temettüat defteridir. Osmanlı arşiv kayıtları arasında önemli bir yere sahip olan bu defterler, nüfus defterleri ile devrin beşeri ve ekonomik tarihi için önemlidir. Temettüat, sözcük olarak kazanç, kâr etme anlamına gelen "temettü/temettü" sözcügünün çoğuludur. Günümüzde ticaret malı anlamında sık kullandığımız "meta" sözcüğünden gelir. Temettüat defteri, Tanzimat Fermanı ile yeniden düzenlenen vergi sistemi için yapılan servet yoklama kayıtlarıdır. ${ }^{4}$ Bu hususta 1839 tarihinde çıkarılan bir talimatla, vergi yükümlüsü vatandaşların adı, şöhreti, arazileri, hayvanları ile tüccar ve esnaf grubunun yıllık gelirleri ve diğer hususların kayıt altına alınması emredilmiştir. Tanzimat'a kadar değişik adlarla tahsil edilen vergilerin yerine, tek bir verginin ikamesi için hane reislerinin gelirlerinin tespiti amacıyla yapılan sayımların kaydedildiği defterlere temettüat defteri denilir. ${ }^{5}$

19. Yüzyılın ortasında (1260-1261/1844-1845) vergi sistemi ile ilgili düzenlenmiş kayıtların ilk sayım denemesi 1256/1840 yılında pilot bölgelerde yapılmıştır. Bu kayıtlar forma ve içerik bakımından 18441845 yılına ait kayıtlardan daha farklıdır. 1256/1840 yılına ait defterlerde ekili dikili alanların kıymeti yer alırken, diğerinde 1260/1844 yılına ait yıllık geliri yer almıştır. "Kıymet" hanesi çıkartılmış, yerine "hasılatı senevi” ibaresi yer almıştır. Bu defterlerin çoğu taşradan mahalle veya köy adına gönderilen tek bir idari birim adına kayıtlı defterlerdir. ${ }^{6}$ Bu defterler belirli bir üslup ve bir düzen ile tanzim edilmiştir. Defterde 1260/1844 yılı ödenen vergi kayıtları öşür/aşar, ağnam gibi benzer rüsum ile virgü-yü mahsusa olarak ifade edilen eski vergilerin tek tek kaydı yer alır. Yine bu kayıtlarda 1261/1845 yılı vergi tarhı konulacak malvarlığının servet-kazanç noktasında tespit bilgisi vardır. Hane reisinin varlıklarının en sonunda yıllık kazancına dair tahmini toplam gelir kaydı yazılıdır. Ayrıca defterin sonunda mahalle ya da köy adına toplu özet bilgiler yer alır.

Temettüat defterlerinde yer alan bazı bilgilere değinmek gerekir. Bu defterlerde ekili dikili tarım alanları ayrı ayrı kaydedilmiş, mezru ve gayri mezru olarak o yıl ekilen ya da nadasa bırakılan yerler belirtilmiştir. Buğday (hınta), arpa (şair), burçak, duhan (tütün), afyon (haşhaş), darı (erzen), pamuk (penbe), pirinç, gül,

\footnotetext{
${ }^{3}$ Ek:8 'de yer alan temettüat defterinin son sayfasının üst kısmında köy defter kayıtlarının özet olarak verilen toplam kayıtlar arasında "nüfus mevcudu:87" ibaresi yer almaktadır. BOA.ML.VRD.TMET.d. 9203, s. 22.

${ }^{4}$ Mübahat S. Kütükoğlu, “Osmanlı Sosyal ve İktisadî Tarihi Kaynaklarından Temettüât Defterleri”, Belleten, LIX, (1995), s. 395.

5 Osman Gümüşcü, Tarihi Coğrafya, Yeditepe Yayınevi, İstanbul 2010, s. 279.

6 Tevfik Güran, "XIX. Yüzyıl Temettüat Tahrirleri”, Osmanlı Devletinde Bilgi İstatistik, (H. İnalcık, Ş. Pamuk Der.), Ankara 2000, s. 76.
} 
harnub (keçi boynuzu), dut, limon, portakal, zeytin, yemiş, sarımsak, soğan, börülce, susam, koza, elma, badem, ceviz, bostan açık bir şekilde kaydedilmiştir. Yine tarımın yanında önemli bir geçim kaynağı olan hayvancılığa dair de önemli hususları paylaşmak gerekir. Öncelikle bu defterler sayesinde dönemin hayvancılık faaliyetleri hakkında hane sakinlerinin sahip olduğu hayvanların tür ve sayıları noktasında bilgi sahibi oluyoruz. Koyun, keçi türü küçükbaş hayvanlar, deve, sığır, dana, düve, manda (camus) türü büyükbaş hayvanlar, at, eşek, kısrak, katır, tay, beygir türü binek hayvanları, tarımla uğraşın belirtisi olan çift öküz ya da çift camus kayıtları ile arıcılık faaliyetleri defterde ayrıntılı olarak yer alır. Yıllık getirisine göre vergi kaydı düşülen, süt veren-vermeyen hayvanlara dair "sağmal-yoz" kayıtları yazılıdır. Doğrusu temettüat defteri mal varlığının tespitini amaçlayan bir kayıt çalışması olduğundan, vatandaşın demirbaşı niteliğinde olan ancak vergi alınmayan hayvanlar da listelenmiştir. Odunculuk gibi hane sahibinin sadece kendi özel işinde kullandığı müddetçe hayvanlarından vergi düşülmemiştir. Ancak kâr amaçlı başkasına çalışıldığında ya da kiralandığında vergi düşülmüsstür. ${ }^{7}$ Neticede vergi alınsın, alınmasın hanede var olan bütün hayvanlar kayıt altına alınmıştır. Kuşkusuz bu kayıtlar, eşsiz tarihi bir kaynak özelliği taşımaktadır.

Makalemize kaynak teşkil eden temettüat defteri, Cumhurbaşkanlığ 1 Osmanlı Arşivlerinde BOA. ML. VRD. TMD. d. No: 09203 künyesi ile kayıtlıdır. Defterin kapak sayfasında "Kütahya sancağına tâbi Simav kazası kuralarından İğdiş karyesinin tahrir-i temettüat defteri sene:1261 numara: 66" ibaresi vardır. Defter 1261/1845 yılında 11 sayfa olarak tanzim edilmiştir. Köy sakinlerinden 34 kişi vergi yükümlüsü olarak yer alırken, defterde 32 hane kayıtlıdır. Köyde zanaat erbabı olmadığı gibi hizmetkâr, ırgat, çoban gibi diğer meslek dallarına dair de bir kayıt yoktur. Köy cami imamı 31 no'lu hane reisi olarak, cami hatibi de 20 no'lu hane reisi olarak kayıtlıdır. İmam ve hatip dâhil vergi yükümlüsü olan herkes, ziraat erbabı olarak kaydedilmiştir.

Kayıtlara baktığımızda, kazançların toplamından tek bir vergi ikamesini düzenleyen bir amaç taşıdığı anlaşılır. Bu hususta kayıtların nasıl alındığına bakalım. Vergi mükellefi her hane reisi için hane numarası verilmiş, kişinin sülale ya da lakabı belirtildikten sonra baba adı ile beraber kaydedilmiştir. Hane reisini tanımlayan ibarenin üzerinde yatık şekilde 1260/1844 yılı ödenen aşar, ağnam gibi benzer rüsum ile virgüyü mahsusa olarak ifade edilen eski vergilerin toplamının kaydı yer almıştır. Bu hususta köyde hane reisinin o yıl hasadını yaptığı hububat, baklagiller ile balcılık üzerinden aşar (10/1) vergisi kayıtları yer alır. Köyde hububat olarak buğday, arpa, burçak, yulaf ve darı ile baklagillerden nohut için vergi kaydı kile ve kuruş olarak belirtilmiştir.

Hane reisini tanımlayan ibarenin altında ekili dikili alanlar ile hayvan varlıklarına dair bilgiler sütun sütun ayrı ayrı küme halinde kaydedilmiştir. ${ }^{8}$ Ziraat yapılan tarlaların dönüm bilgisi verildikten sonra hemen altında 1260/1844 ile 1261/1845 yıllarına ait hasattan elde edilen hasılat değeri kuruş olarak yazılmış, aşar vergisi değeri de aynı sütunda "öşrü minhâ" ibaresi ile krş. olarak belirtilmiştir. Bazı hanelerin ortakçılık usulü ziraat yaptığı görülür. Bu noktada ortakçılığın mahiyetine dair çok detaylı bilgi yoktur. Ancak gelir kayıtlarını içeren bir defter olarak, ortak ziraat yapılan tarlanın dönüm bilgisi, ortakçıının kim olduğu, gelir kaydı açıkça yazılıdır. Yine kuru tarımın dışında sulu tarımın yapıldığı bağ, bahçe, bostan alanları evlek ya da dönüm olarak kaydedilmiştir. Meyve ve ceviz ağaçları sayı olarak belirtilmiştir. Bunlar için de her iki yıl için ayrı ayrı gelir kaydı düşülmüştür.

Temettüat defterinde hayvan varlıkları, geliri olanlar ve geliri olmayanlar şeklinde iki farklı türde kaydedilmiştir. Ayrıca gelir getiren hayvanlar da kendi içerisinde yoz ve sağmal şeklinde belirtilmiştir. Sağmal hayvanların önce sayısı, sonra yıllık geliri kaydedilmiştir. Bu hususta sağmal hayvanların yıllık

\footnotetext{
${ }^{7}$ Nuri Adıyeke, "Temettuat Sayımları ve Bu Sayımları Düzenleyen Nizamname Örnekleri”, Ankara Ünüversitesi, Osmanlı Tarihi Araştırma ve Uygulama Merkezi Dergisi, OTAM, SAYI 11, 2000, s. 774; Yiğit, İ.-Kocabıyık, M. (2016), “XIX. Yüzyıl Anadolu’sunda Tarımsal Yapı", 2016 Hoca Ahmet Yesevi Yılı Anısına Uluslararası Türk Dünyası Eğitim Bilimleri ve Sosyal Bilimler Kongresi, s. 229230.

${ }^{8}$ Bu hususta makalenin sonunda yer alan ekler kısmında köy temettüat defterinden örnek sayfalara bakılabilir.
} 
hasılatı olarak inek 40 kuruş, koyun 10 kuruş, keçi 6 kuruş; yoz hayvanların hasılatı olarak koyun 3 kuruş, keçi 1 kuruştur. Yoz inek ya da kısır inak için gelir kaydı düşülmemiştir. Yoz hayvanların etinden, yününden ve kılından elde edilen gelir dikkate alınmıştır. Vergi düşmeyen diğer hayvanlar da tek tek adetleri ile ayrıca kaydedilmiştir. Son olarak hanenin arıcılık faaliyetine dair bilgiler yer alır. Kovan baş1 11 kuruş gelir kaydı söz konusudur. Hane reisinin servetine dair bu bilgiler kaydedildikten sonra yıllık toplam geliri tahmini olarak krş. olarak yazılmıştır.

Defterde hanelere dair ayrıntılı kayıtlar sona erdikten sonra köyün temettüatı, hane sayısı, mevcut (erkek) nüfusu, koyun sayısı, virgü-yü mahsusa, 1260/1844 ve 1261/1845 yıllarına ait aşar vergilerinin toplam değerleri özetlenerek verilmiştir. Defterin sonunda köy imamı ve muhtarların kayıtların doğruluğuna dair tasdikli mühürleri, hemen altında da yetkili memurların mühürleri ile defter tescil edilmiştir.

\section{Yeşilova Köyü}

\subsection{Coğrafi Durumu}

Coğrafi mekân olarak Yeşilova Köyü, Gediz-Hisarcık yolu 17. km.'sinde kurulmuş, 1100 rakıml1, karasal iklime sahip tipik bir Anadolu köyüdür. Köy, Gediz-Hisarcık-Emet güzergâhında güney-kuzeybatı istikametinde uzanan, geniş bir vadiyi gören hafif meyilli, ekili dikili alanların arasında yer alır.

Yerleşim merkezi, Gediz depremi sonrası batıya, daha aşağıda taşlık bir zemin üzerine inşa edilmiştir. Gediz depremi, 28 Mart 1970 tarihinde, gece yarısı 7. 2 şiddetinde büyük bir depremdir. Bölge tarihinde derin izler bırakan bu depremde köy evleri orta ölçekte hasar görmüştür. Devlet, köy sakinleri için prefabrik, betonarme panolu evler inşa ederek köylünün barınma sorununu gidermiştir. Planlı bir şekilde inşa edilen, geniş sokakları ve yolları ile öne çıkan bu yapılanma sonrası, sadece köy yerleşim merkezi değişmemiş, aynı zamanda köyün "İğdiş" olan ad1, "Yeşilova" olarak değiştirilmiştir. Böylece köy, GedizHisarcık yolu ile ortadan ayrılmış, köy sakinleri eski yerleşim alanını "yukarı köy", yeni yerleşim alanını da "aşağı köy" olarak isimlendirmişlerdir. Makalemize konu olan "İğdiş karyesi”, bugün "yukarı köy" olarak adlandırılan yerdir.

İğdiş, 1100 rakımı ile çevre köylere kıyasla daha yüksek bir noktada olmasının yanında yüksek dağ ve tepelerin arasında bir vadi üzerindedir. Köyün, kuzey ve kuzeydoğusu gittikçe yükselen, 1600 rakımlarına ulaşan, sıralı dağ tepelerinden oluşan ormanlık alanlarla kaplıdır. Batı yönünde 2120 rakımlı Akdağ (Şaphane Dağı)'1 görür. Köy ile Akdağ etekleri arasında güneydoğu-kuzeybatı istikametinde uzanan, komşu Akkaya Köyü'nü de içine alan geniş ovada kuru tarım yapılır. Ayrıca bu alan içerisinde, ekilmeyen, otlak olarak kullanılan mera alanları da vardır. Yine, köy çevresinde son yıllarda dikili alanların yer almaya başladığı görülür. Kuzeyde, 1600 rakımlarına kadar çıkan sıralı dağlarda uzun kış mevsiminde karlar ve yağışlarla depolanan sular, dere yatakları ile köylere inmekte ve köylerin içme suyu ihtiyacı karşılanmaktadır. Yazları, kurak bir iklime sahip olan köyün su ihtiyacının karşılanmasında kış boyu depolanan bu sular önemli bir kaynaktır. Doğrusu güz, kış ve bahar mevsimlerindeki yağışlar ile devam eden bir döngü söz konusudur.

Tarihi "İğdiş" köy yerleşim merkezi, doğudan batıya doğru uzanan, hafif meyilli, ekili dikili alanlar arasında, bir dere kenarına kümelenmiş, yan yana dizilmiş, iki katlı ahşap bağdadi evlerden oluşur. Bugün, bu evlerden çok azı günümüze ulaşmıştır. Bunun yanında, geriye kalan bu yapılardan ve artıklarından nasıl bir yerleşim alanı olduğunu çıkarmak mümkündür. Günümüzde kullanılmaya devam eden az sayıdaki bu evler, yöreye özgü inşa edilen doğal yalıtımlı bağdadi evlerdir. Çok ince taş ve ahşap ustalığı gerektiren, alt katı ahır, üst katı oturma alanı olarak kullanılan, yöresel evlerdir. Osmanlı oluklu kiremitleri ile örtülü ahşap çatısıyla orta Anadolu'nun kerpiçli ev mimarisinden çok farklıdır. Cumbalı evlerin nadir de olsa bulunduğu bu köy evlerinin iç kısımlarında ahşap süslemeler dikkati çeker. 
Köy, Türkiye'nin kaderi olan kırsaldan kente işgücü göçünden payını almıştır. Bilindiği üzere kırsaldan kente işgücü göçünü etkileyen iki unsur söz konusudur. İlki, 1950'ler sonrası tarımda makineleșme ile işsizliğin artması ve 1980'ler sonrası şehirlerdeki sanayileşme ile işgücü arzının artmasıdır. Kentlerdeki işgücü arzına işsiz köy sakinleri talip olmuştur. Bu esas iki unsurun yanında bölgede etkili olan unsurlardan birisi de 1970-Gediz depremidir. Bu bakımdan günümüz köy sakinlerinin çevredeki büyük yerleşim merkezleri başta olmak üzere, İzmir ile yurt dışında Almanya ağırlıklı işgücü göçü söz konusudur. Günümüzde tarım, hayvancılık ve küçük ölçekli esnaflık köyün geçim kaynaklarıdır. Köy arazilerinde modern ziraatçılık yapılmakta, köylüde çiftçilik için gerekli son model tarım makinaları, traktörler, biçerdöverler bulunmaktadır. Özellikle köy çevresinde, köy sakinlerinden bazılarına ait küçükbaş hayvan yetiştirme çiftlikleri önemli üretim merkezleridir.

Harita: 1 Kütahya Gediz Yeşilova Köyü'nün ülke ve il genelindeki coğrafi konumu.

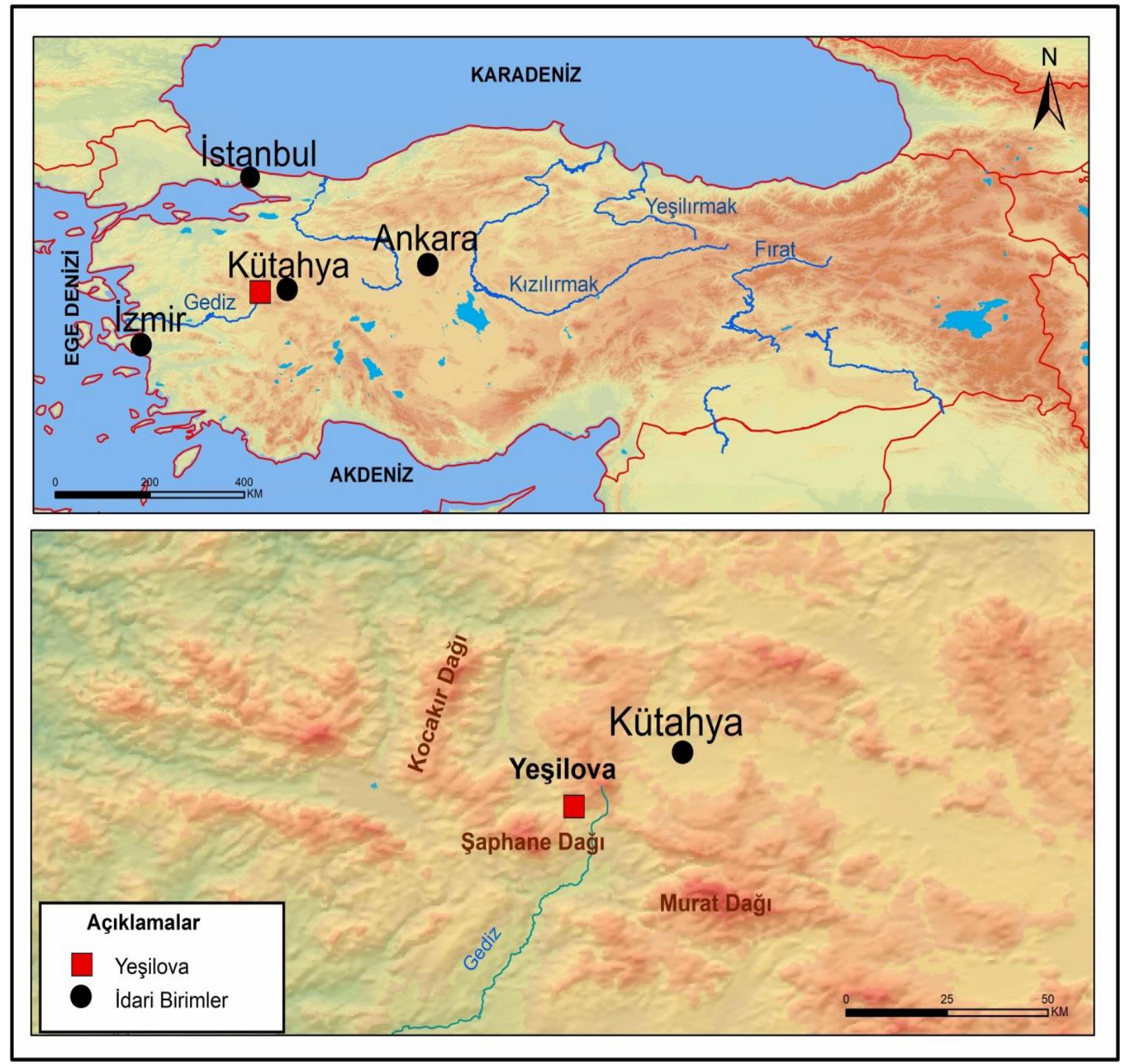




\section{2. "İğdiş" ve Anlamına Dair}

Köy coğrafi yapısına dair bilgileri aktardıktan sonra, köyün önceki adı olan "İğdiş" ile ilgili bilgi vermek yerinde olacaktır. İğdiş, Osmanlı döneminde olduğu gibi Cumhuriyet döneminde 1970'lere değin köy adı olarak kullanılmıştır. Hatta kuruluşundan beri bu adı taşıdığını söylemek mümkündür. Anadolu'yu fetih sonrası iskân eden Oğuz Türkleri yaşam biçimlerine göre yeni köyler kurmuşlar ve bu köylere Türkçe adlar koymuşlardır. Önceki yerleşim yerlerine ya da yakınlarına kurulan köylerin çok azı önceki adı ile anılmıştır. Bugün evren, ören, viran, virancık vb. adları taşıyan köy ya da kasabalar önceki yerleşim yerlerine yakın yerlerde kurulan yerleşim merkezleridir. Günümüzdeki köy adlarının çoğu Osmanlı öncesi dönemde konulmuş, kurulduğu günden beri de aynı adlar kullanılmıştır.

İğdiş, sözcük olarak kadim Türk tarihi kaynaklarında9 ${ }^{9}$ yer alan en eski Türkçe sözcüklerden birisidir. Anadolu Selçuklu devri vakfiyelerinde,${ }^{10}$ hatta Karahanlı devri bir sikkede ${ }^{11}$ İğdiş sözcügüne rastlanır. Köy adına da Osmanlı arşiv kayıtlarında, "Iğgiş" adı ile 1500'lerde ${ }^{12}$ hatta öncesinde yer aldığ görülür. Bu hususta köy adının, köyün kuruluş evresine dair ışık tuttuğu da söylenebilir. Doğrusu bu ad, Anadolu'daki yaygın köy adlarına nispetle nadir kullanılan adlardandır. Anadolu'ya yerleşen Oğuz Türkmenlerinin yeni yerleşim yerlerine Türkçe adlar koyduklarından söz ettik. Bu hususta Osmanlı 15. yy. arşiv belgeleri dikkate alınarak yapılan çalışmalar, ${ }^{13}$ bu durumu teyit etmektedir. Çevre köy adlarına baktığımızda, genelde coğrafi yapıyı öne çıkaran isimler söz konusudur. Dolayısıyla köye, "İğdiş" adının verilmesi dikkat çekicidir.

İğdiş, sözcüğü ile alakalı tarihçiler ve dilciler çok özel ilmi çalışmalar yapmışlardır. Tarihçilerden Prof. Dr. Faruk Sümer'in Türkiye Diyanet Vakfı İslâm Ansiklopedisi’nde yer alan "İğdiş”, maddesi ${ }^{14}$ ile "Selçuklu Tarihinde İğdişler" 15 adlı makale çalışması öncü çalışmalardır. Prof. Dr. Tuncer Baykara'nın "Selçuklular Devrinde İğdişlik ve Kurumu" 16 adlı makale çalışması da Ortaçağ tarihi metinleri dikkate alınarak sözcük ve kurumsal bir yapının adı olarak ele alınmıştır. Dilcilerden Prof. Dr. Serkan Şen'in "İğdiş̧ Sözcüğü Nereden Geliyor"17 başlıklı çalışması sözcüğün anlam ve biçim bilimi noktasında değerlendirilmesidir. Yine dilcilerden Doç. Dr. Erdem Uçar, "Kutadgu Bilig Dizinindeki Bir Kelime Hakkında VIII: İğdiş ve İğdişçi Sözcüğü’18 başlıklı çalışmasında sözcüğün anlamına odaklı bir çalışma yürütmüştür.

Tarihi kaynakları ve söz konusu çalışmaları dikkate aldığımızda iğdiş, "eğitmek, beslemek, yetiştirmek" anlamında "igitmek" sözcüğünden türemiştir. Karahanlı Türkçesi’nde "igdişçi” sözcüğü "besleme, büyütme, yetiştirme" ve "hayvan yetiştiricisi" anlamına gelir. Farsça'da "melez" anlamda "ikdiş" ya da

\footnotetext{
9 Yusuf Hâs Hacib, Kutadgu Bilig, (nşr. Reşit Rahmeti Arat), Ankara 1947, s. 172, 299, 446, 555; Kaşgarlı Mahmud, Dîvânü lugâti'tTürk, c. I, s. 183. Kaşgarlı’nın eserinde benzer biçimdeki sözcüğü Ökdeş olarak okuyanlar vardır.

10 Osman Turan, Türkiye Selçukluları Hakkında Resmi Vesikalar, Ankara 1958, s. 178.

11 Karahanlı devri 602/1205-6 tarihli Benaket’te basılmış bir sikkede, "Uluğ Ĭğdiş Çağrı Han" adına rastlanır.

Tuncer Baykara, "Selçuklular Devrinde İ̆dişlik ve Kurumu”, Belleten, LX, 226, s. 689.

12 Iğdiş Köyü’ne dair 1530 tarihli tahrir defterinde Simav kazası Çengi nahiyesine tâbi karye kaydı söz konusudur. Bu konuda bkz. 370 Numaralı Muhâsebe-i Vilâyet-i Rûm-ili Defteri (937/1530), Kütahya, Kara-hisar-i Sâhib, Sultan-önü, Hamîd ve Ankara Livâları, Ankara 1993, c. I, s. 38.

${ }^{13}$ Cevdet Yakupoğlu, “Aslanapa Yöresinde Türk İskânının Belgeleri: Yer ve Şahıs Adları (XII-XVI. Yüzyıllar)”, Uluslararası Batı Anadolu Beylikleri Tarih, Kültür ve Medeniyet Sempozyumu-III Germiyanoğulları Beyliği 8-10 Mayıs 2014, Bildiriler Kitabı, Yayına Hazırlayanlar: Mehmet Ersan-Mehmet Şeker, Türk Tarih Kurumu, Ankara 2017, s.423-472.

14 Faruk Sümer, "Iğdiş", Türkiye Diyanet Vakfı İslâm Ansiklopedisi, c. XXI, 2000, s. 524-525.

15 Faruk Sümer, "Selçuklu Tarihinde İ̆dişler", Türk Dünyası Araştırmaları, Sayı:35, 1985, s. 9-23.

16 Tuncer Baykara, "Selçuklular Devrinde İğdişlik ve Kurumu", Belleten, LX, 226, s. 681-693.

17 Serkan Şen, "iğdiş Sözcüğü Nereden Geliyor?", ilmî Araştırmalar, Sayı: 23, 2007, s. 123-190.

18 Erdem Uçar, "Kutadgu Bilig Dizinindeki Bir Kelime Hakkında VIII: İ̆giş ve İğdiş̧i Sözcüğü”, Korkut Ata Türkiyat, Uluslararası Türk Dili ve Edebiyatı Araştırmaları Degisi, Cilt:1, Sayı: 1, Aralık 2019, s. 11-18.
} 
“yikdiş” biçiminde melez atlar için kullanılmıştır. Divânü Lügâtü’t-Türk'de ise sözcük, "ana bir kardeş"19 anlamında kullanılmıştır. Serkan Şen, sözcügün biçimine dair tarihi kaynaklardaki kullanımına dair tenkitini yaptıktan sonra sözcügün "hayvan yetiştirme işi” ile ilgili olduğunu, hatta günümüzde kullanılan "hadım edilmiş at", tanımından anlaşılacağı üzere bu işlem ile hayvanın enerjisinin vazifeli olduğu işe yoğunlaşacağını yazar. Yani hadım edilen at, besiye çekilmiş ise semizleşir, sabana koşulmuşsa uysal ve dirençli olur, binek ise hızı ve dayanıklılığı artar, şeklinde özetler. Bu hususta sözcüğün kökeninin "melez" anlamında kullanıldığı Farsça "ikdiş" değil, söz ettiğimiz anlamıyla Türkçe "iğdiş" olduğu üzerinde durur. Doğrusu Serkan Şen'in bu görüşüne destek mâhiyetinde Ortaçağ tarihi metinlerinde iğdiş sözcüğü çok yerde geçer. XIII. ve XIV. yüzyıllarda Anadolu'dan Suriye ve Mısır'a devlet adamlarına hediye olarak takdim edilen atlara iğdiş denir. Arapça metinlerde "ikdiş" (çoğulu:ekâdîş) olarak geçer. ${ }^{20} \mathrm{Bu}$ atların babalarının Arap, annelerinin Türk atları olduğu ve çok hızlı koştukları kaydedilir. ${ }^{21}$

Erdem Uçar, "iğdiş” sözcüğünün Kutadgu Bilig'de bugünkü anlamından farklı kullanıldığı tezi üzerinde durarak, insan ve hayvanlar için kullanılan ortak sözlerden olduğuna dikkat çeker. İnsan için besleme, evlatlık, hizmetçi; hayvan için iğdiş edilmiş, burulmuş hayvan, bilhassa at anlamında kullanıldığını yazar. "İğdişçi”, sözcüğünün ise "at iğdiş edip yetiştiren” bir meslek grubu olarak gösterir ve bu tezi üzerinde durur.

Sözcüğün kurumsal bir yapının karşılığı olarak kullanımına gelince, Faruk Sümer ve Tuncer Baykara, iğdiş sözcüğünün Anadolu Selçuklu Devleti'nde şehirlerde ticari hayatta söz sahibi bir mevkii olarak şehir esnaf ve eşrafından sayılan bir kesime ad olarak kullanıldığını vurgularlar. Sümer, XII. yüzyıldan itibaren Anadolu'da Selçuklu şehirlerinde iğdiş teşkilatının varlığına değinir. Sarayın, ordunun ve halkın ihtiyaçlarını karşılamak, zenaat erbabının, güçsüz insanların hayatlarını kolaylaştırmak; kısaca şehir ve şehirlerarası ticari hayatın akışından sorumlu bir teşkilat olduğuna dikkat çeker. Kurumun başı olarak "İğdiş-başı" şehir hayatını kontrol eden kişidir. Hatta Anadolu'da Moğol-ïlhanlıların hâkimiyeti ile vergi tahsildarlarına verilen isim olur. XIV. Yüzyıldan sonra da devlet ve toplumda giderek önemini kaybeden iğdişlik kurumunun yerini ahîler alır. Tuncer Baykara, Anadolu Selçuklu şehirlerindeki esnaf teşkilatını iğdişlik ve ahîlik olarak iki kısma ayırırken, ahîlik öncesi esnaf teşkilatının adı olduğuna dikkat çeker. Ticari hayatın düzenlenmesinde, üstlendikleri önemli görevlerinden bahseder. Şehirlerin eşrafı olarak halkın temsilciliğini deruhte ettiklerini, şehirlerde iğdiş ve iğdiş-başı olduğunu kaynaklarıyla bahseder. İğdiş-başı, şehir halkını temsil eden, şehrin ticari hayatından sorumlu, üst düzey yetkili birisidir. Üretim ya da küçük ölçekli işlerden ziyade büyük ölçekli işlerle ticari faaliyet yürütür. Koyun ve at besleme, en önemli uğraşlarıdır. XIII. yüzyılın ikinci yarısından itibaren (Moğol istilâlarının da etkisinden olsa gerekir ki) şehirlerde ahîlik teşkilatı önem kazanır. Baykara, son söz olarak iğdiş sözcüğünü; "Anadolu'da XII.-XV. Yüzyıllar arasında ticaretle uğraşan, hayvan besleyip halkı doyurduğu için”, bu adın kullanılmış olmasına temas eder. ${ }^{22}$ Kurum olarak XIII. Yüzyılda Anadolu'da makam sahibi ve meslekler siralamasında 1. grup devlet erkânı olarak öne çıkan "İğdişlik emiri" taşrada üst düzey görevlilerden birisidir. Son olarak bu dönem taşrada ekonomik hayatı düzenleyen önemli bir mevkiinin adıdır. ${ }^{23}$

Ortaçağ Türk tarihçiliğinin öncülerinden İsmail Hakkı Uzunçarş1lı ile Uzunçarşılı'dan etkilenen Osman Turan melez kelimesini dikkate alarak iğdiş sözcüğünü, Anadolu Selçuklu devri şehirlerin güvenliğinden

\footnotetext{
19 Burada "ikdiş" olarak değil de, "ökdeş" olarak okuyanlar da vardır.

20 Şemseddîn eş-Şücâî, (ö. 745/1344), Târîhu'-I-Meliki'n-En-Nâsırî Muhammed bin Kalavun es-Sâlihî ve Evlâdihî, (Thk. Barbara Schafer), Wiesbaden 1977, s. 22; Makrîzî, Kitâbü's-Sülûk li-Ma'rifeti Düveli'l-Mülûk, I-IV, (Thk. Muhammed Mustafa Ziyade-Said Abdülfettah Âşûr), Kahire 1934, 1958, c. II, s. 430-431, 394, 415, 490.

${ }^{21}$ Sümer, a.g.m., s. 524-525.

22 Tuncer Baykara, "Selçuklular Devrinde İ̆dişlik ve Kurumu", Belleten, LX, 226, s. 681-693.

23 Hasan b. Abdülmü’min el-Hôyî'nin Kaleminden Selçuklu İnşâ Sanatı (Haz. Cevdet Yakupoğlu-Namiq Musalı), Türk Tarih Kurumu Yayınları, Ankara 2018, s. 96-97, 173.
} 
sorumlu, Müslüman olmuş Hıristiyan çocuklardan teşkil edilen askeri bir sınıf $\operatorname{ad}^{24}$ olarak ifade ederler. Ancak yukarıda bahse konu çalışmalarda bu görüş tenkit edilmiş, sonuçta kabul görmemiştir.

Bu bilgilerden sonra köy adı ile alakalı bazı düşüncelerimizi aktaralım. İlhanlı devri vergi tahsildarlarına verilen bir isim olması hasebiyle yakın çevredeki idari yerleşim merkezinde görevli bir "İğdiş başı" ya da "İğdiş emiri” için köyün yıllık geliri bu memura tahsis edilmiş olabilir. Köy adının bununla alakası olabilir. Yine Akkaya olarak isimlendirilen komşu köyün önceki adı Merkepviran/Merkepören ya da Eşek Viranı'dır. Köy tarihine baktığımızda Gediz kazasına tâbi Eşek Viran ismine Osmanlı arşivlerinde 870/1465 tarihli Kütahya Piyade defterinde rastlamak mümkündür. ${ }^{25}$ Dolayısıyla her iki köyün 1400'lere değin varlığ 1 söz konusudur. Komşu köyün adının "Eşek" ile anılmasına karşılık "İğdiş" adının yukarıda temas ettiğimiz üzere "at" ile alakası olmalıdır. Köyde bugün de varlığını koruyan mera alanları devrin meşhur iğdiş atlarının yetiştirildiği bir yer olabilir. Adını da buradan alabilir. Bu meyanda at yetiştiriciliği aynı zamanda atın beslenmesi ve terbiye işlerini de kapsamaktadır. İhtimal o ki, bugün dahi otlak olarak kullanılan Alan, Küçükköy, Selimkaya mevkileri bu iş için uygun mera alanlarıdır. Bu üç yerin arasında kalan kısımların zamanla tarıma açıldığı, zamanında mera olduğu nesilden nesle aktarılan bilgiler arasındadır. Temettüat defterinde "resmi nebat" adı ile kayıtlı çayır/ot vergisi dikkat çeker. Defterde 18 hane için bir kuruşluk nebat/çayır vergisi kaydı vardır. Bu bilgiler çerçevesinde "iğdiş" adlı at yetiştiriciliği anlamı ağır basmaktadır.

İğdiş anlamına dair son zayıf bir ihtimal de, Farsça, melez anlamı ile alakalı olmasıdır. Köy kuruluşuna dair nesilden nesle aktarılan çevre köy sakinlerinin bir araya gelmesiyle kurulduğuna dair sözlü gelenektir. Toplama, karışık anlamında melez olarak kullanılmış olabilir.

\section{Köy Yönetimi}

Makalemizde kullandığımız arşiv kayıtlarında İğdiş Köyü Simav Kazası'na tâbidir. Yine bu kayıtlarda birinci muhtar, ikinci muhtar ile köy imamının üçünün birlikte köy yönetiminde sorumlu olduğu defterlerdeki mühürlerden ve nüfus yoklama kayıtlarındaki bilgilerden tespit etmek mümkündür. Nüfus ve temettüat defterlerinde imam ve muhtarların kim olduğuna dair kayıtlar vardır.

Köy yönetiminden sorumlu olan "muhtarlık” kurumu, Osmanlı'da 1830'lardan itibaren ülke genelinde yaygınlaştırılmıştır. Devlet işleri ile alakalı özellikle vergilerin tespiti ve tahsili noktasında önemli görevleri vardır. Yine askere alımlar, özellikle ölen doğan kayıtlarının tutulduğu nüfus yoklama defterlerinin imam ve muhtarlar tarafından verilen bilgilere göre kaydedildiği açıkça yer alır. Bu hususta kayıtlardan ve mühürlerden bu bilgileri takip etmek mümkündür. Bu bakımdan çalışmamızla alakalı köy temettüat defterinin sonunda köylüye ait bilgileri tasdik ettiklerine dair metnin alt kısmında üçüne ait mühürler ile görevli memurların evrakı tescili anlamına gelen mühürler yer alır. Makalenin sonunda ekler kısmında bu sayfayı görmek mümkündür.

İmam ve muhtarlara ait mühürlere dair bilgi vermek yerinde olacaktır. Devlet işlerinin takibi için tahsis edilen mühürler 1250 (1834-35) yılında hazırlandığı üzerindeki tarihten anlaşılmaktadır. Ayrıca mühürlerde kişi adları olmayıp icra ettikleri görevler köy adı ile kazınmıştır. İmam mühründe "İmam-1 der Karye-i İğdiş 1250", (İğdiş Karyesi İmamı), birinci muhtar mühründe "Muhtar-1 evvel der Karye-i İğdiş 1250", (İ̆gdiş karyesi birinci muhtarı), ikinci muhtara ait mühürde "Muhtar-1 sânî der karye-i İğdiş" (İğdiş karyesi ikinci muhtarı) ibareleri yazılıdır.

Nüfus ve temettüat defterlerinde imam ve muhtarların kim olduğunu belirten kayıtları defterlerde görmek mümkündür. Bu hususta bilgi verelim. Nüfus defterinde, ilk hane reisi imam olarak kayıtlıdır. Bu kayda göre "Koca Ahmet oğlu" sülalesinden "Süleyman oğlu Mehmet" köy imamıdır. Birinci muhtar 2

24 Osman Turan, Türkiye Selçukluları Hakkında Resmi Vesikalar, Ankara 1958, s. 178.

25 BOA, TT, 3M, s. 136. 
no'lu hane reisi "Hac1 oğlu" sülalesinden "Hacı Mehmet oğlu Halil”, ikinci muhtar 3 no'lu hane reisi "Değirmenci oğlu" sülalesinden "Ahmet oğlu Mehmet" ${ }^{26}$ tir. Nüfus defterinde ilk üç hanede imam ve sırasıyla muhtarlar kayıtlıdır. Temettüat defterine göre bir imam ve bir hatip kayıtlıdır. İmam, 31 no'lu hane reisi "İmam oğlu" sülalesinden "Ahmet oğlu Mehmet”tir. Hatip, ise 20 no'lu hanede kayıtl "Hamırc1 oğlu" sülalesinden "Hüseyin oğlu Hacı Süleyman"dır. Bu kayıtta hatip, aynı zamanda birinci muhtar olarak kayıtlıdır. İkinci muhtar nüfus defterinde olduğu gibi aynı kişidir. Ayrıca Köyde 23 no'lu hanede 60 numara ile kayıtlı 25 yaşındaki “ Mehmet oğlu Şerif”, "mansûrede” yani orduda olduğu kayıtlıdır. Bu ordu yeniçeri ocağının kaldırılmasıyla alakalı yeni bir anlayışla kurulmuş olan, "Asâkir-i Mansûre-i Muhammediye" ordusudur.

\section{Köy Nüfus Özellikleri}

Nüfus defterine göre köyde 31 hane, 78 erkek nüfusu kayıtlıdır. Temettüat defterlerinde ise vergi yükümlüsü 32 hane, 87 (erkek) nüfus mevcudu kayıtlıdır. Kadın nüfus ile beraber toplamda yaklaşık 200 nüfuslu bir köy olduğunu söylemek mümkündür.

Tablo: 1 Nüfus defterlerine göre kişi adları ve oranları

\begin{tabular}{|c|c|c|c|}
\hline \multicolumn{4}{|c|}{ Nüfus Defterinde Geçen Kişi Adları ve Yüzdelik Oranları } \\
\hline No & Kişi Adları & Say1s1 & Yüzdelik \% Oranı \\
\hline 1 & Mehmet & 19 & 17,27 \\
\hline 2 & Ali & 13 & 11,81 \\
\hline 3 & Süleyman & 11 & 10 \\
\hline 4 & Hüseyin & 10 & 9,09 \\
\hline 5 & İbrahim & 10 & 9,09 \\
\hline 6 & Hasan & 6 & 5,45 \\
\hline 7 & Ahmet & 6 & 5,45 \\
\hline 8 & Halil & 6 & 5,45 \\
\hline 9 & Mustafa & 5 & 4,54 \\
\hline 10 & Veli & 4 & 3,63 \\
\hline 11 & Yusuf & 3 & 2,72 \\
\hline 12 & Murat & 3 & 2,72 \\
\hline 13 & Şerif & 3 & 2,72 \\
\hline 14 & İsmail & 3 & 2,72 \\
\hline 15 & Osman & 3 & 2,72 \\
\hline 16 & Ömer & 2 & 1,81 \\
\hline 17 & Mahmud & 2 & 1,81 \\
\hline 18 & Nasuh & 1 & 0,9 \\
\hline
\end{tabular}

Köyde kullanılan kişi adları, köyün dini ve etnik yapısını göstermesi açısından önemlidir. Doğrusu yaklaşık iki yüzyıl sonra günümüzde hâlâ aynı adlar kullanılmaktadır. Müslüman kimliğe işaret eden bu

26 Nüfus defterinde "Mehmet" şeklinde okumak mümkündür. Ancak temettüat defterinde açıkça "Mahmut” yazılıdır. 
isimlerin en çok kullanılanı Hz. Muhammed'e atfen Türkler arasında yaygın olarak kullanılan "Mehmet" ismidir. Günümüzde nüfus istatistiklerine göre "Mehmet" adı en çok kullanılan isimler arasında varlığını korumaktadır. Köy nüfus defterinde, "Mehmet" isminin kullanılma oranı \% 16'dır. Sirayla Ali, Süleyman, Hüseyin, İbrahim olarak devam etmektedir. Diğer isimlerin kullanım oranı aşağıda tabloda yer alır. Köy sakinleri arasında Türkçe kökenli bir adın yer almaması dikkat çekicidir. Bu durum köyde adlarının dini temelli olduğunu gösterir.

Tablo:2 Nüfus ve temettüat defterlerinde yer alan sülale adları:

\begin{tabular}{|c|l|l|}
\hline No & Sülale Adları (Nüfus Defteri) & Sülale Adları (Temettüat Defteri) \\
\hline 1 & Koca $^{27}$ Ahmed Oğlu & Koca Ahmet Oğlu \\
\hline 2 & Hacı Oğlu & Hac1 Oğlu \\
\hline 3 & Değirmenci Oğlu & Değirmenci Oğlu \\
\hline 4 & İmam Oğlu & İmam Oğlu \\
\hline 5 & Murat Oğlu & Murat Oğlu \\
\hline 6 & Dana Kazık Oğlu & Dana Kazı Oğlu \\
\hline 7 & Beyaz Oğlu & Beyaz Oğlu \\
\hline 8 & Uzun Oğlu & Uzun Oğlu \\
\hline 9 & Kuruoğlan ${ }^{28}$ Oğlu & Kuru Oğlu \\
\hline 10 & Dudu Oğlu & Dudu Oğlu \\
\hline 11 & Deli Hasan Oğlu & Deli Hasan Oğlu \\
\hline 12 & Keçeci Oğlu & Keçeci Oğlu \\
\hline 13 & Kir Ali Oğlu & Kir Ali Oğlu \\
\hline 14 & Hamırc1 Oğlu & Hamırc1 Oğlu \\
\hline 15 & Çatal Oğlu & Çatal Oğlu \\
\hline 16 & Kel Ali Oğlu & Kel Ali Oğlu \\
\hline 17 & Hacı Hasan & Hac1 Hasan \\
\hline 18 & Kara Ahmet Oğlu & Kara Veli Oğlu \\
\hline 19 & & Kara Deli Oğlu \\
\hline 20 & & Kel Hasan Oğlu \\
\hline
\end{tabular}

Nüfus defterinde 18 sülale adı yer alırken, temettüat defterinde 20 sülale adı yer alır. Bazen bir sülaleden tek bir hane yer alırken bazen de aynı sülale adı altında birkaç hane yer almaktadır. Sülale adlarında fiziki özellikler daha çok öne çıkmakta, bunun yanında imamlık, değirmencilik, keçecilik gibi meslek adlarının da sülale adı olarak kullanıldığı görülmektedir. Yine kişinin tavır ve davranışlarından kaynaklı yakıştırılan sülale adları vardır.

${ }^{27}$ Nüfus defterinde "Kısa", olarak okumak mümkün ise de, temettüat defterinde açık bir biçimde "Koca" yazmaktadır.

28 Nüfus defterinde "Kuruoğlan Oğlu" olarak geçerken temettüat defterinde sadece "Kuru" ifadesi yer alır. Aynı kişi olduğu her iki defterdeki kayıtlardan anlaşılmaktadır. 
Köyde hangi sülaleden kaç hane ve bu hanelerdeki toplam nüfus sayısı liste olarak aşağıda yer almaktadır. Hane sırasına göre düzenlenen bu listeye göre en kalabalık sülaleler Hamırcı Oğlu, Dana Kazık Oğlu olarak sırasıyla yer almaktadır.

Tablo 3: Nüfus defterinde yer alan sülale adları ve nüfusları

\begin{tabular}{|l|c|c|}
\hline \multicolumn{2}{|c|}{ Sülalelerin Hane Sayısı ve Erkek Nüfus Adedi } \\
\hline Sülale Adı & Hane & Nüfusu \\
\hline Hamırcı Oğlu & 5 & 10 \\
\hline Dana Kazık Oğlu ${ }^{29}$ & 2 & 12 \\
\hline Murat Oğlu & 2 & 7 \\
\hline İmam Oğlu & 2 & 5 \\
\hline Kel Ali & 2 & 7 \\
\hline Dudu Oğlu & 2 & 4 \\
\hline Kuru Oğlan & 2 & 4 \\
\hline Deli Hasan & 2 & 4 \\
\hline Kır Ali & 2 & 2 \\
\hline Keçeci Oğlu & 2 & 2 \\
\hline Uzun Oğlu & 1 & 6 \\
\hline Koca Ahmet & 1 & 4 \\
\hline Değirmenci Oğlu & 1 & 2 \\
\hline Beyaz Oğlu & 1 & 2 \\
\hline Kara Ahmet & 1 & 3 \\
\hline Çatal Oğlu & 1 & 1 \\
\hline Hacı Hasan & 1 & 1 \\
\hline Hacı Oğlu & 1 & $\mathbf{7 8}$ \\
\hline Toplam & $\mathbf{3 1}$ & \\
\hline
\end{tabular}

\section{Köy Mesleki Yapılanması}

Sanayi öncesi toplumların temel geçim kaynağı olan tarım ve hayvancılık, bu dönem Anadolu'da köy hayatını belirleyen önemli iki unsur olarak varlığını sürdürmektedir. Doğrusu aile emeğine ve çift öküz gücüne dayalı tarım işletme biçimi ${ }^{30}$ geçerliliğini sürdürmektedir. Bu noktada mevsimlere göre işlenen topraktan, temel besin maddeleri hububat ve baklagiller temin edilirken, basit birer işletmeci olan köylü, ihtiyacı olan süt ve et ürünlerini de kendi beslediği hayvanlar ile tedarik etmeğe çalışmıştır.

Köy sakinlerinin geçim kaynakları tarım ve hayvancılık olmasının yanında yörenin ekonomik faaliyeti ve geçim kaynaklarına değinmek yerinde olacaktır. Köylünün temel ihtiyaç malzemelerini tedarik etme ve günlük işlerinde kullandığı araç gereçleri temini noktasında en yakın pazar yeri Gediz'de ${ }^{31}$ kurulur. Bu Pazar yeri, "Gediz Pazarı" adı ile türkülere konu olmuştur. ${ }^{32}$ Bu noktada Gediz merkez nüfusun

${ }^{29}$ Nüfus defterlerinde 2 hane olarak yer alan Dana Kazık Oğulları sülalesi temettüat defterlerinde yine 2 hane olarak görünmektedir. Dikkat çeken husus bu sülaleden vergi yükümlüsü 4 kişi kaydedilmektedir.

30 Halil İnalcık, Osmanlı Imparatorluğu: Toplum ve Ekonomi, Eren Yayıncılık, İstanbul, 1996, s. IX.

31 Günümüz Eski Gediz kasabası tarihi Gediz kentinin merkezidir.

32 Gediz ve çevresinde yaygın bir biçimde söylenen ve dizelerinden yakılan bir ağıt olduğu anlaşılan türkünün dizeleri şöyledir:

Gediz pazarıdır benim pazarım

Akdağ Yaylası'nda kaldı mezarım 
çoğunluğunun geçim kaynağının çeşitli esnaf kollarından oluşması ${ }^{33}$ dikkat çekicidir. Bu durum yöre ve bölge ticareti açısından önemlidir. Dolayısıyla, yakın köy ve mezraların ihtiyaçlarının tedariki konusunda önemli olan Gediz nahiye merkezi, Yeşilova Köyü'ne 11 km. uzaklıktadır. Ulaşım vadi boyunca o dönem şartlarında binek hayvanları üzerinde ya da at arabaları ile sağlanmaktadır.

Yeşilova Köyü'nün yer aldığg Gediz-Hisarcık güzergâhı üzerinde vadi boyunca yer alan komşu köylerin o dönem geçim kaynaklarına değinelim. Gediz nahiye merkezinde değişik esnaf kolları yanında dokumacılık sektörü dikkat çekici bir boyuttadır. Bu noktada 138 hane çulhacılık işi yaparken, toplamda 332 hane dokumacılık işi ile uğraşmaktadır. Bunun yanında Gediz'de toplam 1049 hanenin üçte biri dokumacılık kolunda emek harcamaktadır. ${ }^{34}$ Yine Gediz'e en yakın köylerinden kalabalık bir nüfusa sahip 221 hane kayıtlı Akçaalan Köyü temettüat defterine ${ }^{35}$ göre köy sakinlerinin yarısı dokumacılık işi ile uğraşmaktadır. Bu haneler çulha esnafı olarak kayıtlıdır. Küçük ölçekli komşu köylerden 21 haneli Akkaya Köyü, ${ }^{36} 18$ haneli Aşıkpaşa Köyü ${ }^{37}$ ile 18 haneli Soğuksu Köyü ${ }^{38}$ kuru tarım ve hayvancılık ile geçimini sürdürmekte, Değirmenköy ${ }^{39}$ su değirmenleri ile çok eski tarihlere giden bir geçmişe sahiptir. Yine aynı güzergâh üzerinde bulunan 75 haneli Kayaköy ${ }^{40}$ ve 68 haneli Yeşilçay ${ }^{41}$ köyleri kuru tarımın yanında sulu tarıma müsait arazi şartlarına sahiptir. Diğer köylere kıyasla kalabalık olan bu köylerde bağcılık, meyvecilik, bahçe ve bostan üretimi yapılmaktadır. Yeşilova Köyü'nün yakın çevresinde yer alan bu yerleşim birimlerinin geçim kaynakları yörenin sosyo-ekonomik hayatına dair ipuçları verir. Yeşilova Köyü

Ne diyeyim, Ay Ahmet! Ne diyelim Allah'tan oldu

Bizim (bizim) kavuşmamız mahşere kaldı

Hisarköy'den çıktım başım selamet

Akdağ yaylasında koptu kıyamet

Beni vuran Uzunoğlu De'l Ahmet

Ne diyeyim Ay Ahmet! Ne diyelim Allah'tan oldu

Bizim (bizim) kavuşmamamız mahşere kaldı

${ }^{33}$ Bu dönem Gediz'de birçok meslek kuruluşu vardır. Giyim eşyaları üreten dikimci, haffaf, terzi, yemenici, kunduracı, babuşçu; dokumacılık iş kolunda faaliyet yürüten kirbas esnafı, pamuk tüccarı, çulhacı, boyacı, çıkrıkçı, bezci; gıda iş kolunda faaliyet yürüten değirmenci, duhancı, ekmekçi, helvacı, kasap, kebapçı, leblebici, manav, şerbetçi, yağcı; üretip satan mesleklerle ilgili de attar, debbağ, bardakçı, demirci, eskici, saraç, semerci, oduncu; hancı, kahveci; inşaat iş kolunda faaliyet yürüten dülger, neccar, tahtacı, taş̧̧ı, yapıcı, su yolcusu; taşımacılıkla uğraşan katırcı, kiracı, yolcu; temizlik iş kolunda faaliyet yürüten hamamcı, tellak, berber; hizmet üreten meslekler olarak hekimlik, sünnetçi, nalbant, küfeci, kalaycı, kahveci, hancı, odabaşı; kamu hizmetini deruhte eden, yönetim ve asayişten sorumlu görevliler ile dini hizmetlerde vazifeli kimseler şehirde öne çıkan meslek sahipleridir. Hüseyin Göksal, 19. Yüzyıl Ortalarında Gediz'in Sosyal ve Ekonomik Tarihi, Gediz Belediyesi Kültür Yayınları, 2013, s. 28-39.

34 Göksal, a.g.e., s. 26.

35 BOA. ML. VRD. TMT. d. 7921. Akçaalan Köyü hakkında Osmanlı Arşiv kayıtlarında en eski kayıt 1 Safer 854/25 Mart 1450 tarihli evkaf suretinde yer alır. Söz konusu belge, Gediz'de Murat Bey Zaviyesi için, İsfendiyar oğlu Yakup Bey oğlu Murat Bey tarafından köy gelirlerinin vakıf olarak tahsisi söz konusudur. BOA. EV. VKF. 17-45.

${ }^{36}$ BOA. ML. VRD. TMT. d. 7905. Akkaya Köyü adı Osmanlı arşiv kayıtlarında 870/1465 tarihli Kütahya Piyade defterinde geçer. BOA, TT, 3M, s. 136.

37 BOA. ML. VRD. TMT. D. 09264. 1480'lerde II. Bayezid devri yazıldığını düşünülen Mufassal Evkaf Tahrir Defteri'nde Şeyh Paşa Mezrası olarak geçer. Bu kayıtlar köy tarihinin çok eskilere gittiğini gösterir. MAD. d. 262, s. 209.

38 BOA. ML. VRD. TMT. d. 09251.

39 BOA. ML. VRD. TMT. d. 09255. Değirmen Köy, Osmanlı arşivlerinde en erken tarihlerde rastlamak mümkündür. 1 Safer $854 / 25$ Mart 1450 tarihli evkaf suretinde köy adı geçer. Belgede Simav kazası Çengi nahiyesine tâbi Değirmen Köyü’nde bulunan Pınarbaşı mevkiindeki üç değirmenin gelirleri Gediz Murat Bey Zaviyesi için tahsis edilmiştir. BOA.EV.VKF. 17-45.

40 BOA. ML. VRD. TMT. d. 09196. Kayaköy, Karye-i Kaya adı ile 870/1465 tarihli Kütahya Piyade defterinde geçer. BOA. TT. D. 3., S. 122.

${ }^{41}$ BOA. ML. VRD. TMT. d. 09213. Yeşilçay, Çengi nahiyesi olarak bugünkü yerleşim yerinin yer aldığını düşündüğümüzde 854/1250 tarihli evkaf suretinde adı geçer. BOA. EV. VKF. 17-45. Yine Karye-i Çay olarak geçtiğini düşündüğümüzde 870/1465 tarihli Kütahya Piyade Defterinde geçer. BOA. TT. D. 3., s. 124. 
adı geçen köyler arasında çiftçilik varlığı bakımından öne çıkmakta, kuru tarım açısından da gelir kaydı en fazladir.

Geçim kaynağı tarım ve hayvancılık olan Yeşilova Köyü'nde kayıtlı 32 haneden 30'u ziraat erbabıdır. Diğer 2 haneden birisi mecnun, diğeri de kiralama usulü tarlası bir başkası tarafından işletilmektedir. Ayrıca iki hanede birden fazla vergi yükümlüsü vardır. Bir no'lu hanede 2 kişi, 10 no'lu hanede 3 kişi arazi ve hayvanatından kazanç sağlamakta ve vergi ödemektedir. Çiftçiliğin yanı sıra köylüye ait kayıtlı hayvan türleri ve sayısı, hayvancıllı̆ın da önemli bir geçim kaynağı olduğunu gösterir. Üç hane için pulculuktan gelir kaydı düşülmüştür. Yani başkalarına bedel karşıllğında çift süren fazla çift öküzleri olan hanelerdir. Köyün tarım ve hayvancılık konusunda ayrıntılı bir biçimde ekonomik faaliyetine değineceğiz.

Köyde tarım ve hayvancılık dışında bir meslek ya da işgücünün olup olmadığına dair kayıtlarda yer almamasına rağmen bazı tespitlerde bulunmak mümkündür. Kayıtlarda olmayan, ancak köy coğrafyası ve yerleşim düzeni dikkate alındığında bazı meslek ve işgücünün var olduğuna temas etmek gerekir. Öncelikle her hanede çift öküz ve merkep bulunmaktadır. Bazı ailelerde de çift manda, katır, kısrak, beygir türü binek hayvanları mevcuttur. Bu hayvanların varlığı dikkate alındığında sadece binek amaçlı değil aynı zamanda taşımacılık için kullanıldığı malumdur. Odunculuk amacıyla hane sahibinin kendi özel işinde kullandığı müddetçe hayvanlarından vergi düşülmediğine dair bilgi vermiştik. Ancak kâr amaçlı başkasına çalışıldığında ya da kiralandığında vergi düşülmüştür. ${ }^{42}$ Dolayısıyla köy çevresindeki zengin orman kaynakları köylünün ihtiyacı olan yakacak temini noktasında önemlidir. Bunun yanında son yüzyılın ortalarına değin odunculuk önemli bir geçim kaynağıdır. Köylü merkep, kısrak, katır, beygir türü hayvanlarıyla en yakın Gediz'e odun götürüp satmaktadır. Gediz halkı az sayıda bağcılıkla uğraşan, nüfusun çoğunluğunun meslek erbabı olduğuna temas etmiş idik. Dolayısıyla tahıl, hububat ve yakacak ihtiyacını köylülerden karşılamaktadırlar. ${ }^{43}$ Yeşilova sakinlerinin de tahıl, hububat ve yakacak satarak karşılığında evin ihtiyaçlarını karşıladıkları bilinir. Özellikle bu iş için çarşı pazarın kurulduğu gün tercih edilir. Dolayısıyla odun taşımacılığı ve satışı yılın en sakin mevsimlerinde arz ve talebe göre yapıldığından bahisle köylüye gelir getiren kaynaklardan birisidir.

Yeşilova ve çevre köy evleri betonarme yapılar öncesinde, yöreye özgü taş ve ahşap ustalığı gerektiren genelde çift katlı bağdadi evlerdir. Bu evlerin yapımı için gerekli taş, kireç taşı ile kereste köy çevresinde mevcuttur. Taş temel üzerinde birbirine kilitlenmiş, yekpare ardıç ya da çam direklerle karkası inşa edilen bu yapıların duvarları kireç-saman-toprak karışımı harç ile doldurulur, sonra kuruyan duvar sıvanır, üzeri kireçli su ile badanası yapılır. Genelde iki katlı; alt katı dam, üst katı oturma alanıdır. Dolayısıyla bu evlerin yapımında gerekli malzemeler köy çevresinden temin edilmektedir. Hem bu malzemelerin tedarik edilmesinde, hem de bu evlerin inşa edilmesinde köy sakinlerinden yararlanıldığı, hatta bu evleri inşa eden ustaların köy sakinlerinden olması yüksek ihtimaldir. Her ne kadar temettüat defterlerinde, usta olanların kaydına rastlanmasa da köy sakinleri arasında usta olanların varlığını kabul etmek gerekir. Günümüzde yüz yaşlarında olan kimselerin çocukluk evrelerinde, köy sakini olan onlarca usta adını sayması, bu tezimizi güçlendirir. Doğrusu inşaat ustalığı temel ihtiyaçlar arasındadır. Ancak ne nüfus defterlerinde, ne de temettüat defterlerinde usta lakaplı kişiler ya da usta olarak kazancından dolayı gelir kaydı düşülen kimselere rastlanılmamaktadır. Her işin nüvesinde olduğu gibi her meslek erbabının daha çocukluk yaşta işe başladığı, sırayla çıraklık, ustalık ve kalfalık ile devam ettiği ya da uzun bir süre bir deneyim sonrası ustalığı söz konusudur. Durum bu olunca hasat zamanı dışında usta olanların köyde ya da çevre köylerde hatta daha uzak yerlerde ustalık yaptıklarını söylemek mümkündür. Yine köylülerden birçoğunun hasat zamanı daha erken gelen kıyıya yakın batı bölgelerine giderek bağ bahçe işleri, hasat işleri ile uğraştıkları, yevmiye usulü para kazandıkları yaşlılardan dinlenilen anılarla belirginleşir.

\footnotetext{
${ }^{42}$ Adıyeke, a.g.m., s. 774; Yiğit, İ.-Kocabıyık, M. (2016), “XIX. Yüzyıl Anadolu'sunda Tarımsal Yapı”, 2016 Hoca Ahmet Yesevi Yılı Anısına Uluslararası Türk Dünyası Eğitim Bilimleri ve Sosyal Bilimler Kongresi, s. 229-230.

${ }^{43}$ Göksal, a.g.e., s. 28-39.
} 
Temettüat defterinde köylünün çiftçilik için en önemli varlığı, demirbaşı olan çift öküz kaydı önemlidir. Köylüye ait 54 çift öküz ile 7 çift camus/manda kayıtlıdır. Dolayısıyla köylünün ziraat için sabanın kurulması, bakım ve onarımı vs. işlerin de ustalık gerektiren önemli ince işler olduğu düşünüldüğünde ve bu alanda ustaların köy sakinlerinden olduğu bir hakikattir. Yine köy sakinleri arasında basit el emeği ile ev araç ve gereçlerinin tamir ve bakımından anlayan kişilerin de varlığını kabul etmek gerekir. Doğrusu yıl boyunca kazançlarını bu meslek ya da el becerileri ile yaptıkları uğraşlar karşılığında temin etmeyip ihtiyaç ve zaruret halinde ya da boş kaldıkça uğraşları olduğundan olsa gerekir ki, bu hususta gelir kaydı yazılı değildir. Doğrusu gelir kaydı olarak toprak gelirleri, ağnam/küçükbaş hayvan geliri, sağmal hayvanların gelirleri ile arıcılık faaliyeti üzerinden 1260/1844 yılı vergi kayd1, 1261/1845 yılı için de gelir kaydı temettüat defterinde ayrıntılı bir biçimde yazılmıştır.

Tablo: 4 Köydeki hane reislerinin meslekleri ve 1261/1845 yılı kazançları

\begin{tabular}{|c|c|c|c|}
\hline No & Hane Reisi & Meslek & Kazançları (kuruş) \\
\hline 1 & Koca Ahmet oğlu Mehmet b. Süleyman & Erbab-1 Ziraat & 694 \\
\hline 1 & Biraderi Halil b. Osman & Erbab-1 Ziraat & 284 \\
\hline 2 & Hacı oğlu Halil b. Mehmet & Erbab-1 Ziraat & 1453,5 \\
\hline 3 & Değirmenci Oğlu Mahmut b. Ahmet & Erbab-1 Ziraat & 1815 \\
\hline 4 & İmam Oğlu Mehmet b. İbrahim & Erbab-1 Ziraat & 741,5 \\
\hline 5 & İmam Oğlu Halil b. İbrahim & Erbab-1 Ziraat & 429,5 \\
\hline 6 & Murat Oğlu Hüseyin b. Murat' & Erbab-1 Ziraat & 869,5 \\
\hline 7 & Murat Oğlu Hasan b. Ali & Mecnun & \\
\hline 8 & Hacı Hasan Oğlu Mehmet b. Hasan & Erbab-1 Ziraat & 1465 \\
\hline 9 & Dana Kazık Oğlu Yusuf b. Yusuf & Erbab-1 Ziraat & 735 \\
\hline 10 & Dana Kazık Oğlu Mehmet b. Halil & Erbab-1 Ziraat & 1399 \\
\hline 10 & Mehmet'in kardeşi Ali b. Halil & Erbab-1 Ziraat & 858 \\
\hline 10 & Mehmet'in biraderi Halil b. Süleyman & Erbab-1 Ziraat & 339 \\
\hline 11 & Beyazoğlu Ahmet bin Mehmet & Erbab-1 Ziraat & 490 \\
\hline 12 & Uzun oğlu Mehmet bin İbrahim & Erbab-1 Ziraat & 467,5 \\
\hline 13 & Kuru oğlu İbrahim b. Süleyman & Erbab-1 Ziraat & 1145 \\
\hline 14 & Kuru oğlu Mehmet b. Süleyman & Erbab-1 Ziraat & 808 \\
\hline 15 & Dudu oğlu Ali b. Mustafa & Erbab-1 Ziraat & 1260 \\
\hline 16 & Dudu oğlu Hüseyin b. Hasan & Erbab-1 Ziraat & 825,5 \\
\hline 17 & Deli Hasan oğlu Hacı İbrahim b. Hasan & Erbab-1 Ziraat & 1542 \\
\hline 18 & Keçecioğlu Veli b. Yusuf & Erbab-1 Ziraat & 520 \\
\hline 19 & Kır Ali oğlu Veli b. Ali & Erbab-1 Ziraat & 904,5 \\
\hline 20 & Hamırcıŏlu Hacı Süleyman bin Huseyin & Erbab-1 Ziraat & 2171 \\
\hline 21 & Hamırc1 İbrahim b. Mehmet & Erbab-1 Ziraat & 640,5 \\
\hline 22 & Hamırcıoğlu Hüseyin b. Mehmet & Erbab-1 Ziraat & 667,5 \\
\hline 23 & Hamırcı oğlu Hacı Ahmet b. Ali & Erbab-1 Ziraat & 1435 \\
\hline 24 & Hamırcioğlu Ahmet b. Hasan & Erbab-1 Ziraat & 497,5 \\
\hline 25 & Çatal oğlu İbrahim b. Hasan & Erbab-1 Ziraat & 526,5 \\
\hline 26 & Kel Ali oğlu İsmail. b. Ali & Erbab-1 Ziraat & 658,5 \\
\hline 27 & Kel Ali oğlu Mehmet b. İbrahim & Erbab-1 Ziraat & 779 \\
\hline
\end{tabular}




\begin{tabular}{|l|l|l|r|}
28 & Kara Deli oğlu Ahmet b. Mehmet & Erbab-1 Ziraat & 949 \\
\hline 29 & Kara Veli oğlu Hasan b. Mustafa & Erbab-1 Ziraat & 1198,5 \\
\hline 30 & Keçeci oğlu Nasuh b. Veli & Erbab-1 Ziraat & 609,5 \\
\hline 31 & İmam oğlu Molla Mehmet b. Ahmet & Erbab-1 Ziraat & 422,5 \\
\hline 32 & Kel Hasan oğlu Mustafa b. Ali (zevcesi Raziye) & & 270 \\
\hline & & TOPLAM & 29485 kuruş \\
\hline
\end{tabular}

Tabloya bakıldığında hane reislerinin meslekleri ve yıllık kazançları kuruş olarak yer almaktadır. Meslek olarak iki hane reisi hariç hepsi ziraat erbabıdır. Listede 7 no'lu hane reisi mecnun olarak kaydedilirken, 32 no'lu hane reisinin kayıp olduğu, eşi Raziye tarlalarını kiraya vererek işlettiği için 270 kuruş gelir kaydı düşülmüştür. Üzerine kayıtlı emlak, arazi ve hayvan yoktur. Ayrıca temettüat defteri kayıtlarına göre 1 no'lu hanede 2 vergi yükümlüsü, 10 no'lu hanede de 3 vergi yükümlüsü kayıtlıdır. Köylünün yıllık toplam gelir kaydı 29485 kuruştur.

\subsection{Ziraat Faaliyetleri}

Köy temettüat defterinde hane reisinin işlettiği tarlaların dönüm bilgisi ile yıllık hasılat yer alır. Kayıtlara baktığımızda köyde toprakların, üç çeşit işletildiği görülür. Kendi tarlasını ekip biçenler, şerik yani ortakçılık usulü işletenler ve arazisi kiralama usulü başkası tarafından işletilenlerdir. Bizzat kendisi, ortakçılık ve kiralama usulü toprak işletme biçimi vardır. Aşağıda tabloda yer aldığı üzere işletilen mezru tarla toplamı 841 dönümdür. Köyde ziraat yapılan arazilerden 779 dönüm tarla hane sahibi tarafından işletilirken, 32 dönüm tarla ortakçılık, 30 dönüm tarla icar/kiralama usulü ekilmektedir. Kayıtlarda nadasa bırakılan ya da ekilmeyen tarla kaydına rastlanılmamıştır. Oysa diğer köylere ait temettüat defterlerinde bu hususta "gayri mezru" ibaresi ile kayıtlar vardır. Aşağıda toprak işletme biçimlerine dair tarla dönüm bilgileri hem toplamda hem de hane bazında tablolarda yer almaktadır.

Tablo:5 Köyde işletilen arazilerin dönüm ve işletim şekli tablosu.

\begin{tabular}{|c|c|c|c|}
\hline Kendisi & Ortakç11k & Kiralama & Toplam \\
\hline 779 dönüm tarla & 32 dönüm tarla & 30 dönüm tarla & 841 dönüm \\
\hline
\end{tabular}

Tablo: 6 Hane reislerinin tarla işletme tablosu.

\begin{tabular}{|l|l|c|c|}
\hline $\begin{array}{c}\text { Hane } \\
\text { No }\end{array}$ & \multicolumn{1}{|c|}{ Hane Reisi } & \multicolumn{2}{c|}{ Tarla -Dönüm } \\
\cline { 2 - 4 } & \multicolumn{1}{|c|}{ Kendi mülkü } & Ortak \\
\hline 1 & Koca Ahmet oğlu Mehmet b. Süleyman & 7 & 8 \\
\hline & Biraderi Halil b. Osman'ın & 8 & \\
\hline 2 & Hacı oğlu Halil b. Mehmed & 50 & \\
\hline 3 & Değirmenci Oğlu Mahmud b. Ahmed & 25 & \\
\hline 4 & İmam Oğlu Mehmet b. İbrahim & 33 & \\
\hline 5 & İmam Oğlu Halil b. İbrahim & 10 & \\
\hline 6 & Murat Oğlu Hüseyin b. Murat' & 14 & 10 \\
\hline 7 & Murat Oğlu Hasan b. Ali & & \\
\hline 8 & Hacı Hasan Oğlu Mehmet b. Hasan & 61 & \\
\hline 9 & Dana Kazık Oğlu Yusuf b. Yusuf & 25 & \\
\hline
\end{tabular}




\begin{tabular}{|c|c|c|c|}
\hline 10 & Dana Kazık Oğlu Mehmet b. Halil & 40 & \\
\hline & Mehmet'in karındaşı Ali b. Halil & 40 & \\
\hline & Mehmet'in biraderzadesi Halil b. Süleyman & 15 & \\
\hline 11 & Beyazoğlu Ahmet bin Mehmet & 15 & \\
\hline 12 & Uzun oğlu Mehmet bin İbrahim & 4 & \\
\hline 13 & Kuru oğlu İbrahim b. Süleyman & 25 & \\
\hline 14 & Kuru oğlu Mehmet b. Süleyman & 25 & \\
\hline 15 & Dudu oğlu Ali b. Mustafa & 35 & \\
\hline 16 & Dudu oğlu Hüseyn b. Hasan & 30 & \\
\hline 17 & Deli Hasan oğlu Hacı İbrahim b. Hasan & 40 & \\
\hline 18 & Keçecioğlu Veli b. Yusuf & & 3 \\
\hline 19 & Kır Ali oğlu Veli b. Ali & 18 & \\
\hline 20 & Hamırcığlu Hacı Süleyman bin Huseyin & 50 & \\
\hline 21 & Hamırcı İbrahim b. Mehmet & 20 & \\
\hline 22 & Hamırcı oğlu Hüseyin b. Mehmet & 20 & \\
\hline 23 & Hamırcı oğlu Hacı Ahmet b. Ali & 20 & \\
\hline 24 & Hamırcı oğlu Ahmet b. Hasan & 13 & \\
\hline 25 & Çatal oğlu İbrahim b. Hasan & 31 & \\
\hline 26 & Kel Ali oğlu İsmail. b. Ali & 20 & \\
\hline 27 & Kel Ali oğlu Mehmet b. İbrahim & 20 & \\
\hline 28 & Kara Deli oğlu Ahmet b. Mehmet & 20 & 5 \\
\hline 29 & Kara Veli oğlu Hasan b. Mustafa & 25 & \\
\hline 30 & Keçeci oğlu Yusuf b. Veli & & 6 \\
\hline 31 & İmamoğlu Molla Mehmet b. Ahmet & 20 & \\
\hline \multirow[t]{2}{*}{32} & $\begin{array}{l}\text { Kel Hasan oğlu Mustafa b. Ali (Hanımı Raziye)'nin icare verdiği } \\
\text { tarla dönüm }\end{array}$ & 30 & \\
\hline & Mezru tarla toplamı & 779 & 32 \\
\hline
\end{tabular}

\subsection{1. Çiftçilik Varlığı}

Ziraat için günümüzün traktörü ne ise, o dönem için de sabana koşulacak çift öküzlerin varlığı aynı şeydir. Bu bakımdan çift öküz ve çift camus varlığı köydeki çiftçilik varlığını gösterir. Köyde sabana koşulacak toplam 61 çift öküz/camus kayıtlıdır. 32 haneden 7 hanede çift öküz kaydı yoktur. Bu 7 haneden 2 hanede çift camus kaydı vardır. Bu hususta 25 hanede 54 çift öküz ile 5 hanede 7 çift camus kayıtlıdır. Çift öküz sahibi olan hanelerden 5 hanede bir çift öküz, bir hanede 3 çift öküz, bir hanede 4 çift öküz, diğerlerinde 2'şer çift öküz kayıtlıdır. Ziraat erbabı olarak kayıtlı çiftçilik yapan toplam 30 haneden sadece 3 hanede sabana koşulacak hayvan yoktur. Toplam bu bilgilere göre hane başına ikişer çift öküz/manda düşmektedir. Köyde üç hane için de pulculuktan gelir kaydı düşülmüştür. Bu bakımdan bu kayıtlar Anadolu'nun diğer köylerine kıyasla, çiftçilik yapmak için toprağı işleme bakımından köyün çok iyi bir durumda olduğunu gösterir. Kısaca çiftçilik açısından varlıklı bir köydür. Bu hususta 1260/1844 yılına ait 
18 hane için bir kuruşluk nebat/çayır vergisi kaydı vardır. Sabana koşulan hayvanların tüketimi için çayırlık mera alanlarının varlığına işarettir.

Tablo: 7 Köyde çiftçilik varlığ1

\begin{tabular}{|c|c|c|l|}
\hline Çift öküz sayıs1 & Çift manda sayıs1 & Toplam & Hane başına düşen çift öküz-manda oran1 \\
\hline 54 & 7 & 61 & $\% 2,03$ \\
\hline
\end{tabular}

Tablo: 8 Pulculuktan gelir kaydı düşülen hane reisleri ve gelirleri

\begin{tabular}{|c|c|l|}
\hline Hane no & Hane reisi & \\
\hline 6 & Murat oğlu Hüseyin & $300 \mathrm{krş.}$ \\
\hline 10 & Dana Kazık oğlu Mehmet & $300 \mathrm{krş}$. \\
\hline 10 & Dana Kazı oğlu Ali & $500 \mathrm{krş}$. \\
\hline
\end{tabular}

\subsubsection{Toprak Mahsulleri Varlığı}

Köy sakinlerinin topraktan elde ettiği mahsuller hububat olarak buğday, arpa, burçak ve yulaf ile baklagillerden nohut'tur. Ayrıca iki hanede kök boya üretimi kaydı vardır. Hane bazında üretime dair istatistiki bilgiler aşağıda tabloda yer almaktadır. Tabloda mahsullerin 1260/1844 yılı vergi kayıtları yer alır. Bu veriler, aynı zamanda toplam üretim miktarını da barındırır. Toplamda köy adına ödenen aşar/öşür vergisi sırayla şöyledir. Buğday 162 kile, 1312 kuruş; arpa 127 kile, 790 kuruş; nohut 28 kile, 218 kuruş; burçak 9 kile, 70 kuruş; yulaf 4 kile, 24 kuruş; darı 6,5 kile, 39 kuruş'tur. Buğday ve arpa çiftçilik yapan her hanenin ana gelir kaynakları arasındadır. Aşağıdaki tabloda her hane reisinin ödemekle yükümlü olduğu vergi değeri kile cinsinden hububat miktarı ve kuruş olarak para karşılığ 1 yer almaktadır. Bu listede yer alan kile aşar vergisidir. Dolayısıyla kile cinsinden verilen sayının on katı hane reisinin yıllık üretimini "kile" olarak ortaya çıkarır. Bir kilenin yaklaşık 30 kilo olduğunu varsayarsak, toplam kile değerinin 30 ile çarpımı, üretimi yapılan hububatın toplam miktarını "kilogram" olarak yaklaşık değerini verecektir. Sonuçta, her hanenin üretim miktarı toplamı da köylünün üretmiş olduğu hububatın genel toplamıdır. Aşağıda Tablo:11 köylü için tespit edilen vergi ile yıllık üretim miktarının kile olarak toplam değerini gösterir. Ayrıca bu vergilerden hareketle buğday, arpa ve nohut'un yıllık üretim miktarını kg. olarak tespit etmek mümkündür.

Tablo: 9 Köy 1260/1844 yılı hasadı yapılan buğday, arpa, nohut ve burçak üreten hane reislerinin ödediği verginin kile ve kuruş olarak karşıllı̆̆

\begin{tabular}{|l|l|c|c|c|c|c|c|c|c|}
\hline \multirow{2}{*}{ No Hane Reisi } & \multicolumn{2}{|c|}{ Buğday } & \multicolumn{2}{c|}{ Arpa } & \multicolumn{2}{c|}{ Nohut } & \multicolumn{2}{c|}{ Burçak } \\
\cline { 3 - 12 } & & Kile & Krş & Kile & Krş & Kile & Krş & Kile & Krş \\
\hline 1 & Koca Ahmet Oğlu Mehmet & 6 & 48 & 8 & 48 & $1 / 2$ & 4 & & \\
\hline & Biraderi Halil & & & & & & & & \\
\hline 2 & Hacı Oğlu Halil & 8,5 & 68 & 5 & 30 & 2 & 16 & 1 & 7 \\
\hline 3 & Değirmenci Oğlu Mahmud & 7 & 52 & 5,5 & 58 & 1 & 8 & $1 / 2$ & \\
\hline 4 & İmam Oğlu Mehmet & 4 & 32 & 3 & 18 & 1 & 8 & $1 / 2$ & 7 \\
\hline 5 & İmam Oğlu Halil & 4 & 32 & 3 & 21 & 1 & 8 & & \\
\hline 6 & Murat Oğlu Hüseyin & 6 & 48 & 5 & 30 & & & & 3 \\
\hline 7 & Murat Oğlu Hasan & & & & & & & & \\
\hline 8 & Hacı Hasan Oğlu Mehmet & 14 & 112 & 3 & 18 & & & & \\
\hline 9 & Dana Kazık Oğlu Yusuf & 3 & 28 & 4 & 24 & 1 & 8 & & \\
\hline
\end{tabular}


Journal of Ottoman Civilization Studies

NO. 13 (2021), 1-38

\begin{tabular}{|c|c|c|c|c|c|c|c|c|c|}
\hline 10 & Dana Kazık Oğlu Mehmet & 3,5 & 48 & 3 & 18 & $1 / 2$ & 4 & & \\
\hline & Kardeşi Ali & 3 & 24 & 4 & 24 & 1 & 8 & & \\
\hline & Diğer kardeşi Halil & 1,5 & 12 & 1 & 6 & & & & \\
\hline 11 & Beyaz Oğlu Ahmet & 3 & 24 & 3 & 18 & $1 / 2$ & 4 & & \\
\hline 12 & Uzun Oğlu Mehmet & 6,5 & 52 & 3,5 & 21 & 1 & 8 & & \\
\hline 13 & Kuru Oğlu İbrahim & 7 & 56 & 3 & 18 & 1 & 8 & 1 & 8 \\
\hline 14 & Kuru Oğlu Mehmet & 7 & 56 & 4 & 24 & $1 / 2$ & 4 & & \\
\hline 15 & Dudu Oğlu Ali & 4 & 32 & 6 & 36 & 1 & 8 & & \\
\hline 16 & Dudu Oğlu Hüseyin & 5 & 40 & 5 & 30 & & & 1 & 7 \\
\hline 17 & Deli Hasan Oğlu Hacı İbrahim & 5,5 & 44 & 7 & 42 & 1,5 & 12 & & \\
\hline 18 & Keçeci Oğlu Veli & 4,5 & 36 & 3,5 & 21 & $1 / 2$ & 4 & $1 / 2$ & 7 \\
\hline 19 & Kır Ali Oğlu Veli & 4,5 & 36 & 2,5 & 15 & 1 & 4 & $1 / 2$ & 4 \\
\hline 20 & Hamırcı Oğlu Hacı Süleyman & 9 & 72 & 7 & 42 & 2 & 16 & 2 & 14 \\
\hline 21 & Hamırcı İbrahim & 3,5 & 28 & 2,5 & 15 & 1 & 8 & & \\
\hline 22 & Hamırcı Oğlu Hüseyin & 4 & 32 & 2,5 & 15 & 1 & 8 & & \\
\hline 23 & Hamırcı Oğlu Hacı Ahmet & 5 & 40 & 6 & 36 & & & & \\
\hline 24 & Hamırcı Oğlu Ahmet & 3,5 & 28 & 2,5 & 15 & 1 & 8 & & \\
\hline 25 & Çatal Oğlu İbrahim & 3 & 24 & 2,5 & 15 & 1 & 8 & & \\
\hline 26 & Kel Ali Oğlu İsmail & 3 & 24 & 2,5 & 15 & 1 & 8 & 1 & 6 \\
\hline 27 & Kel Ali Oğlu Mehmet & 6 & 48 & 3 & 18 & 1 & 8 & & \\
\hline 28 & Kara Deli Oğlu Ahmet & 5 & 40 & 5 & 30 & 1 & 8 & & \\
\hline 29 & Kara Veli Oğlu Hasan & 8 & 64 & 5 & 30 & 2 & 16 & 1 & 7 \\
\hline 30 & Keçeci Oğlu Nasuh & 3 & 24 & 5 & 30 & 2 & 14 & & \\
\hline 31 & İmamoğlu Molla Mehmet & 1 & 8 & 1,5 & 9 & & & & \\
\hline \multirow[t]{2}{*}{32} & Kel Hasan Oğlu Mustafa & & & & & & & & \\
\hline & TOPLAM & 162 & 1312 & 127 & 790 & 28 & 218 & 9 & 70 \\
\hline
\end{tabular}

Tablo: 10 Köy 1260/1844 yılı hasadı yapılan yulaf ve darı üreten hane reislerinin ödediği verginin kile ve kuruş olarak karş1lığ1

\begin{tabular}{|c|c|c|c|c|c|}
\hline \multirow{2}{*}{$\begin{array}{l}\text { Hane } \\
\text { Sira No }\end{array}$} & \multirow{2}{*}{ Hane Reisi } & \multicolumn{2}{|c|}{ Yulaf } & \multicolumn{2}{|c|}{ Erzen/Darı } \\
\hline & & Kile & Krşs & Kile & Krş \\
\hline 1 & Koca Ahmet Oğlu Mehmet & 1 & 6 & & \\
\hline 2 & Hacı Oğlu Halil & 2 & 12 & & \\
\hline 3 & Değirmenci Oğlu Mahmud & & & 2,5 & 15 \\
\hline 9 & Dana Kazık Oğlu Yusuf & 1 & 6 & & \\
\hline 10 & Dana Kazık Oğlu Mehmet & & & 3 & 18 \\
\hline 13 & Kuru Oğlu İbrahim & & & 1 & 6 \\
\hline & TOPLAM & 4 & 24 & 6,5 & 39 \\
\hline
\end{tabular}


Tablo:11 Köyde 1260/1844 y1lı hububat üretim miktarları

\begin{tabular}{|l|l|l|l|l|l|}
\hline & Kile Olarak & Kile Olarak & Yüzdelik & Kg. Olarak & \multirow{2}{*}{} \\
\cline { 2 - 5 } & Vergi Miktar1 & Ge & Genel Üretim & & \\
\hline Buğday & 162 kile & 1620 kile & 48,14 & 48600 & 1 kile buğday: $30 \mathrm{~kg}$ \\
\hline Arpa & 127 kile & 1270 kile & 37,74 & 33020 & 1 kile arpa $: 26 \mathrm{~kg}$ \\
\hline Nohut & 28 kile & 280 kile & 8,32 & 8960 & 1 kile nohut: $32 \mathrm{~kg}$ \\
\hline Burçak & 9 kile & 90 kile & 2,67 & & \\
\hline Dar1 & 6,5 kile & 65 kile & 1,93 & & \\
\hline Yulaf & 4 kile & 40 kile & 1,18 & & \\
\hline
\end{tabular}

Köylünün topraktan elde ettiği toplam üretim 3365 kile olup yaklaşık yüz tondur. Tabloda görüldüğü gibi hububat üretiminin yarısı buğdaydır. Sırasıyla buğday \% 48,14, arpa \% 37,74, nohut \% 8,32, burçak $\%$ 2,67, darı \% 1,93, yulaf \% 1,18'lik üretim payına sahiptir. Ayrıca yaklaş1k olarak buğday $48600 \mathrm{~kg}$, arpa $33020 \mathrm{~kg}$, nohut 8960 kg'lık üretim ağırlığına sahiptir. İki hanenin de birer evlekten toplam 2 evlek kök boya ektiğine dair kayıt vardır.

Hububat arasında buğday üretimi birinci sıradadır. Bu durum sanayi toplumu öncesinde kırsal bölgelerin tamamı için geçerli bir durumdur. Kuşkusuz bu dönemde buğday, gündelik hayatta çok özel bir yere sahiptir. Birinci sırada temel besin gıdası olmasının yanında ihtiyaç fazlasının satılarak ticari bir emtiaya dönüşür. Anadolu'da köylüler yarım yüzyıl öncesine kadar kış günlerinde at, katır, merkep türü bineklerinin heybelerine yükledikleri buğdayı pazarda satarak, karşı1ığında pazar alış verişi yaptıkları bilinir. Yazın sıcağında ambara doldurulan buğday, hem sofrada hem de pazarda çiftçinin en önemli tüketim ve gelir kalemidir. Velhâsıl en büyük servetidir. Köyün 1260/1844 y1lı buğday üretimi 48,6 tondur.

\subsection{Hayvancılık Faaliyetleri}

Sanayi öncesi toplumlarda, hayvanlar hayatın bir parçasıdır. Köylü işletmesini yaptığı tarımsal faaliyet ile sadece ihtiyacı olan temel besin maddelerini temin etmez. Tarımsal faaliyet ile aynı zamanda hayvan yetiştiriciliği ve üretimi konusunda temel ihtiyaçlarını da tedarik eder. Bu hususta köylü buğday üretimini kendisi için yaparken arpa, yulaf gibi bazı hububat ürünlerini de hayvanları için yetiştirir. Özellikle hasadı yapılan tüm ürünlerin artığı olan saman, hayvan yetiştiriciliği bakımından önemlidir. Köylü hem kendisi için hem de yetiştirdiği hayvanları için ziraat yapmakta, tarlasını ekip biçmektedir. Doğrusu, köylü için ziraat faaliyetleri ile hayvancılık faaliyetleri birbiri ile iç içe olan işletmelerdir.

Temettüat defterinde 1260/1844 yılına ait 18 hane için bir kuruşluk nebat/çayır vergisi kaydı vardır. Bu kayıt köyde çayırlık mera alanlarının varlığına işarettir. Sabana koşulan hayvanlar başta olmak üzere küçükbaş ve büyükbaş hayvanlar için önemli besin kaynağıdır. Biçilip kurutularak kış mevsiminde tüketildiği gibi mevsimsel yăğşlarla yeşeren çayırlık alanlar yaz ve güz mevsiminde açık alanlarda otlayan hayvanlar için önemli besin kaynağıdır.

Temettüat defterlerinde, hane reislerinin sahip olduğu hayvan türlerinin listesi ve bunlardan elde ettiği yıllık gelirler kayıtlıdır. Kayıtlarda köy ve kentlerde meslek gruplarına göre günlük ihtiyaçların karşılanması bakımından çeşitli amaçlar için kullanılan birçok hayvan türünün yetiştirildiği görülür.

\footnotetext{
${ }^{44}$ Vergi miktarı, topraktan elde edilen ürünün onda biridir. Bunun için ondalık, aşar ya da öşür kavramları kullanılır.

${ }^{45}$ Aşar vergisi olarak alınan miktarın "on" ile çarpımı köylünün ürettiği ürünün kile olarak toplam değerini verir.

${ }^{46}$ Genel üretimin toplam değeri "kile" olarak belirlendikten sonra buğday için 30 kg., arpa için 26 kg., nohut için 32 kg. ile çarpımı toplam üretimin kg. olarak değerini verecektir.
} 
Bunları tür olarak üç sınıfta değerlendirmek mümkündür. Gücünden istifade edilenler, gıda temini olarak beslenenler, deri ve dokumacılık sektörüne ham madde temini için beslenen hayvanlardır. Bu noktada ulaşım, taşımacılık, çiftçilik alanlarında hayvanların gücünden istifade edilenler; et, süt, bal gibi temel gıda temin edilmesi için beslenen hayvanlar; derisi ile özellikle küçükbaş hayvanlardan elde edilen yün, yapağ1 ve kıl gibi dokumacılık ve giyim sektöründe ham madde olarak kullanmak için beslenen hayvanlardır. $\mathrm{Bu}$ hususta köylü, ihtiyaç fazlasını satarak hayvan varlığını nakde çevirir. İhtiyaçlarını bu para ile temin eder. Anadolu'da yarım asır öncesine kadar, nüfusun yarısını oluşturan kırsal kesimde, köylünün ekonomik faaliyeti bu şekildedir. Dolayısıyla hayvancılık ülke ekonomisinde köylü-kentli herkesin günlük yaşamında önemli bir faaliyet alanıdır.

Yeşilova Köyü'nde kayıtlara baktığımızda beygir, kısrak, katır, eşek, öküz, manda cinsi yük hayvanları; inek, dana, düve cinsi büyükbaş hayvanlar ile koyun, keçi türü küçükbaş hayvanların yetiştirildiği görülür. Köylüye ait 1261/1845 yılı kayıtlı çift öküz 54 adet, çift camus 7 adet, binek hayvan sayısı toplamı 56 adet, sığır cinsi büyükbaş hayvan sayısı toplamı 204 adet, küçükbaş hayvan sayısı ise 1001 adettir. Aşağıda tabloda hayvan türüne göre sayısal veriler yer almaktadır.

Tablo: 12 Köylüye ait 1261/1845 yılı toplu hayvan varlığı listesi ve bazı hayvanların yıllık hasılat listesi

\begin{tabular}{|c|c|c|c|}
\hline & Adedi & Bir baș hayvan hasılatı & Toplam hasilat1 \\
\hline Çift Öküz & 54 & & \\
\hline Çift Camus/Manda & 7 & & \\
\hline Merkep & 37 & & \\
\hline Kisrak & 5 & 150 ila 80 aras 1 & 640 kuruş \\
\hline Dölsüz Kısrak & 3 & & \\
\hline Katır & 5 & & \\
\hline Beygir & 3 & & \\
\hline Tay & 3 & & \\
\hline Sağmal İnek & 48 & 40 kuruş & 1920 kuruş \\
\hline Yoz İnek & 3 & & \\
\hline Buzağ1 & 48 & & \\
\hline Dana & 30 & & \\
\hline Düve & 14 & & \\
\hline Sağmal Koyun & 90 & 10 kuruş & 900 kuruş \\
\hline Yoz Koyun & 27 & 3 kuruş & 81 kuruş \\
\hline Kuzu & 100 & & \\
\hline Sağmal Keçi & 254 & 6 kuruş & 1524 kuruş \\
\hline Yoz Keçi & 276 & 1 kuruş & 276 kuru \\
\hline Oğlak & 254 & & \\
\hline Toplam adet & 1261 & Y1ll1k Hasılat & 5341 kuruş \\
\hline
\end{tabular}




\subsubsection{Yük ve Binek Hayvan Varlığı}

Köylünün yıl boyunca ulaşımda, yük taşımada, sabana koşumda gücünden yararlandığı hayvanların sayısal verileri aşağıda grafikte gösterilmiştir. Bu hususta hane reislerinin sahip olduğu hayvanların toplamı yazılmıştır. Toplam çift öküz kaydı 54, çift camus 7'dir. Kaslarından yararlanılan diğer hayvanların toplamı sırasıyla merkep 37 adet, kısrak 5 adet, katır 5 adet olup dölsüz kısrak, beygir ve tay 3'er adet kayitlidir.

Grafik: 1 Köyde yük ve binek hayvan varlığını gösteren grafik.

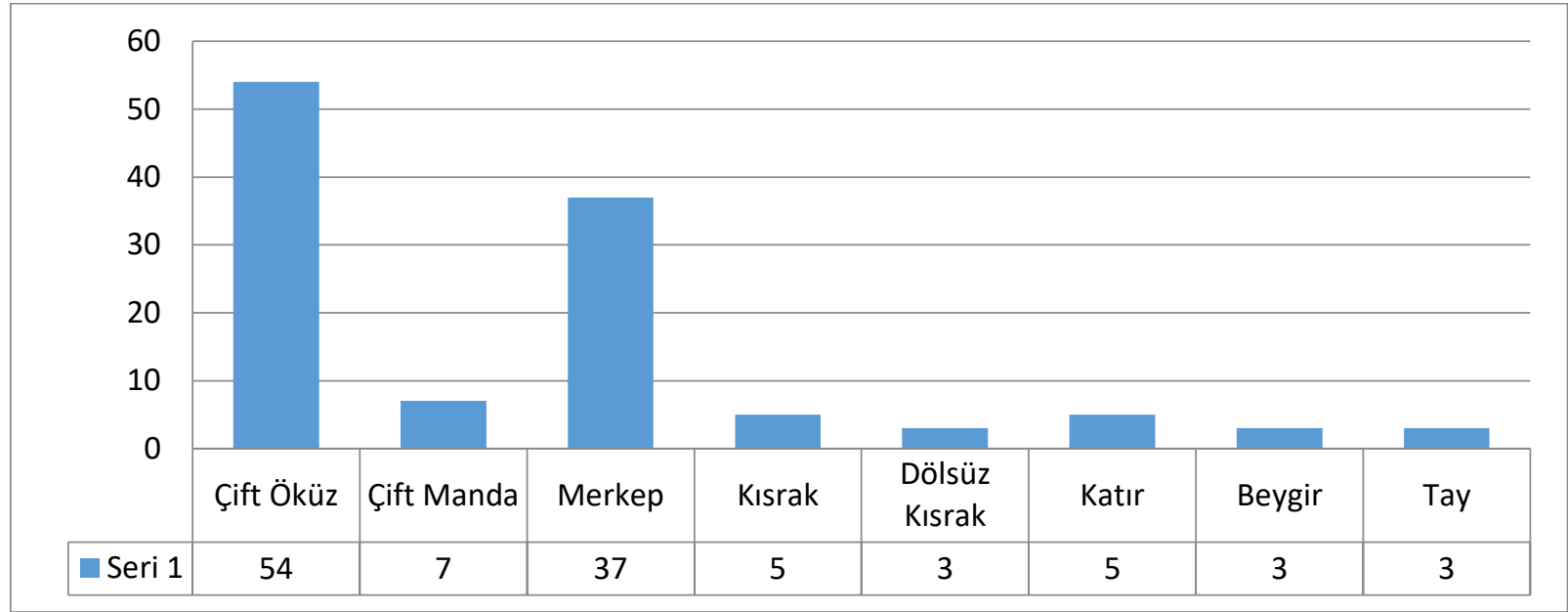

\subsubsection{Büyükbaş Hayvan Varlığı}

Köyde yük ve binek hayvanları dışında büyükbaş hayvanlar inek, yoz inek, dana, düve ve buzağı olarak toplamda 143 adettir. Et ve süt üretiminin yanın alım-satımı yapılarak ticari kazanç sağlayan büyükbaş hayvan köylü için önemli gelir kaynağıdır. Köylünün 1261/1845 y1lı büyükbaş hayvan varlığı toplamda sağmal inek 48 adet, buzağı 48 adet, dana 30 adet, düve 14 adet, yoz inek 3 adet olarak kayıtlıdır.

Grafik:2 Büyükbaş hayvan varlığını gösteren grafik

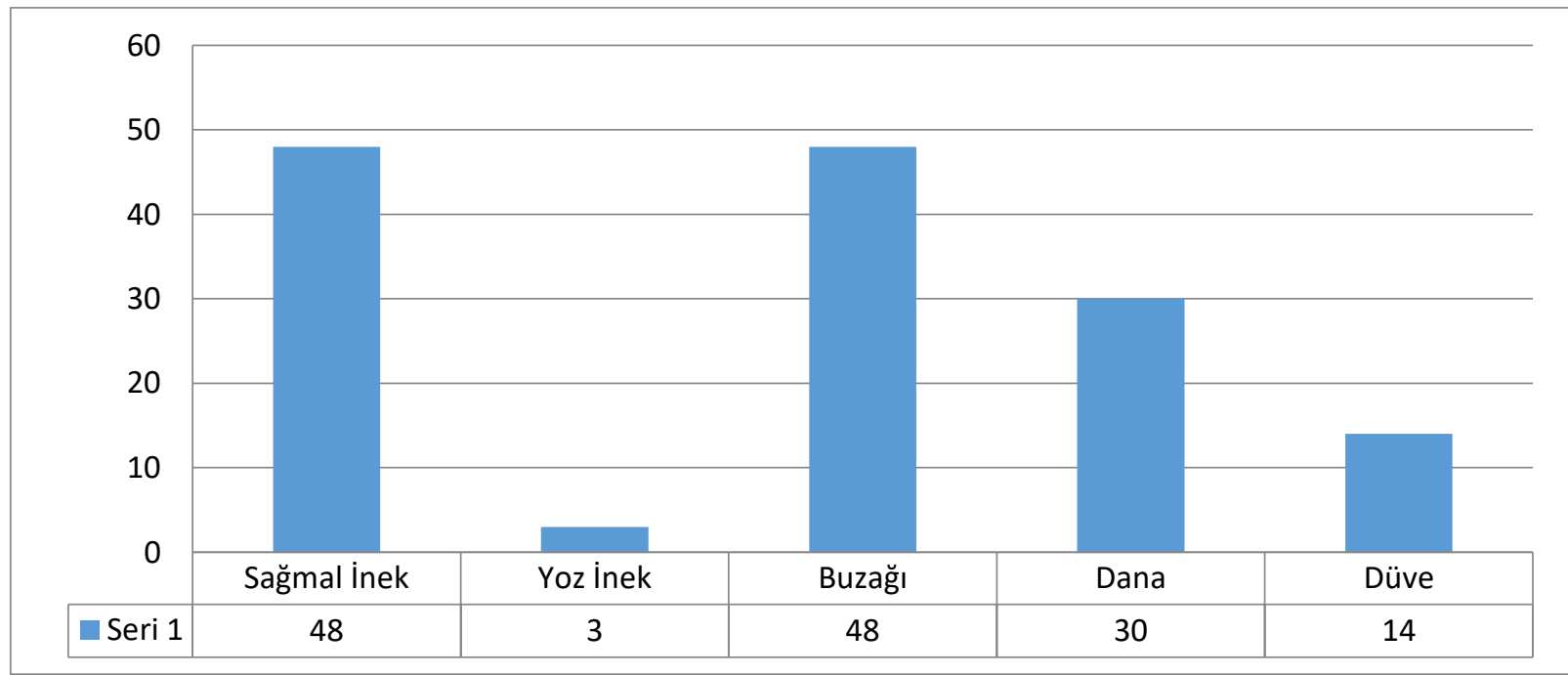




\subsubsection{Küçükbaş Hayvan Varlığı}

Köyde en fazla hayvan varlığı küçükbaş hayvanlardır. Toplamda 1001 adettir. Küçükbaş hayvanlar et, süt tüketimi yanında deri, yün, yapağı, kıl gibi dokuma ve giyim sektöründe gerekli ham madde kaynağıdır. Köylünün 1261/1845 yılı küçükbaş varlığ̣ toplamda sağmal koyun 90 adet, yoz koyun 27 adet, kuzu 100 adet, sağmal keçi 254 adet, yoz keçi 276 adet, oğlak 254 adet olarak kayıtlıdır.

Grafik: 3 Küçükbaş hayvan varlığını gösteren grafik.

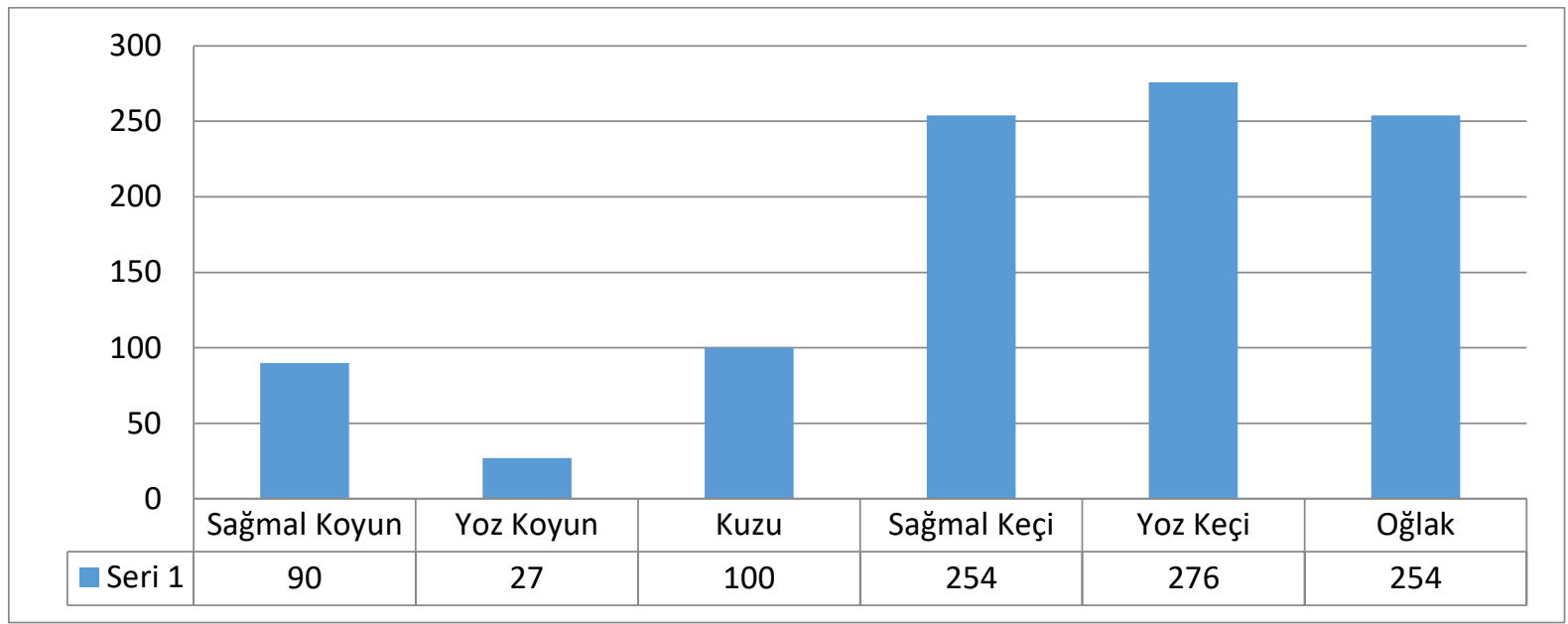

\subsubsection{Yıllık Gelir Sağlayan Hayvanlar}

Gelir kaydı düşülen hayvanlar süt üretim kaynağı olan inek, koyun ve keçidir. Köylü ve kentli her kesimin temel tüketim maddelerinden birisi süt ve süt ürünleridir. Yoğurt, kaymak, çökelek, tereyağı ile peynir türlerinin üretimlerinin kaynağı süttür. Anadolu'da her yörenin kendine özgü süt ürünleri meşhurluğu ile bilinir. Özellikle peynir çeşitleri sayısızdır. Bu anlamda köylünün üreterek tükettiği, hatta ihtiyaç fazlasını nakde çevirdiği süt ürünleri, köylünün önemli geçim kaynaklarından birisidir. Ayrıca küçükbaş hayvanların hepsi yün, yapă̆ı ve kı1 üretim kaynağıdır.

Köyde gelir kaydı düşülen hayvanlar sağmal inek, sağmal koyun, yoz koyun, sağmal keçi, yoz keçi ve kısrak cinsi hayvanlardır. Yıllık gelir toplamı dikkate alınarak yapılan hesaplamada inek 40 kuruş, koyun 10 kuruş, keçi 6 kuruş; yoz hayvanların gelirinde koyun 3 kuruş, keçi 1 kuruş olarak gelir kaydı düşülmüş̧tür. Gelir kaydı düşülen diğer hayvan ise kısraktır. Köylüye ait 5 kısraktan 80 ila 150 kuruş arası gelir kaydı düşülmüştür. Köylünün gelir kaydı düşülen hayvanların toplam hasılatı 5341 kuruştur. Daha detaylı malumat aşağıda grafikte yer almaktadır.

Tablo: 13 Yıllık gelir kaydı düşülen hayvanlar

\begin{tabular}{|l|c|c|c|}
\hline Hayvanlar & Adedi & Bir Baş Hasılat & Toplam gelir \\
\hline Kısrak & 5 & 150 ila 80 arası & 640 kuruş \\
\hline Sağmal İnek & 48 & 40 kuruş & 1920 kuruş \\
\hline Sağmal Koyun & 90 & 10 & 900 kuruş \\
\hline Yoz Koyun & 27 & 3 & 81 kuruş \\
\hline Sağmal Keçi & 254 & 6 & 1524 kuruş \\
\hline Yoz Keçi & 276 & 1 & 276 kuruş \\
\hline Toplam adet & 700 & Toplam kuruş & 5341 \\
\hline
\end{tabular}




\subsubsection{Arıcılık Faaliyeti}

Anadolu'da balcılık üretimi çok eskiden beri sürdürülen bir tür ticari faaliyettir. Sanayi öncesi dönemde tatlandırıcının ana kaynağı olarak kullanılan bal, aynı zamanda şifa kaynağı olarak özenle saklanıp özenle tüketilen gıdalardan birisidir. Dolayısıyla bu dönem, hemen her yerde bal üretimi söz konusudur. Ülkemizde bugün meşhur adı ile sürdürülen bal üretim faaliyeti çok eskilere gider. Varlığını önemli bir ticari faaliyet olarak korumaktadır.

Köy, arıcılık faaliyeti hakkında hane bazında faaliyetler aşağıda listelemiştir. Köyde 1260/1844 yılında 8 hanede yapılan bal üretiminden toplamda 45 kuruş aşar vergisi tahsisi söz konusudur. Bu kayıtlara göre toplam gelir 450 kuruştur. Yine varlık ve gelir kaydının yapıldığı 1261/1845 yılında 6 hanede arıcılık faaliyeti kayıtlıdır. Bu yıl toplam 39 kovan varlığ üzerinden 393 kuruş gelir kaydı yazılıdır. Köyde arıcılık faaliyetinde hane başına düşen kovan miktarı \%1,25'tir. Bu durum şeker ihtiyacının sadece baldan karşılandığı bir döneme dair önemli bir veridir.

Tablo: 14 Köyde arıcılık faaliyetleri

\begin{tabular}{|c|c|c|l|}
\hline \multirow{2}{*}{ Sıra no } & Hane no & $1260 / 1844$ yılı & $1261 / 1845$ y1lı \\
\cline { 3 - 4 } & 15 & Balcılık vergisi/aşar & Kovan sayısı ve hasılatı \\
\hline 1 & 17 & 20 kuruş & 18 kovan - 162 kuruş \\
\hline 2 & 20 & 5,5 kuruş & 5 kovan - 55 kuruş \\
\hline 3 & 21 & 1 kuruş & \\
\hline 4 & 22 & 1 kuruş & 1 kovan - 11 kuruş \\
\hline 5 & 26 & 1 kuruş & \\
\hline 6 & 29 & 8 kuruş & 7 kovan - 77 kuruş \\
\hline 7 & 31 & 2 kuruş & 2 kovan - 22 kuruş \\
\hline 8 & Toplam & $\mathbf{4 5}$ kuruş & 6 kovan - 66 kuruş \\
\hline & & 39 kovan - 393 kuruş \\
\hline
\end{tabular}

\section{Vergiler}

Köylünün toplam kazancı ve ödemiş olduğu vergilere göz atalım. Temettüat defterinin mühürlü son sayfasında köyün kazancı ve vergi hususunda toplam veriler yer alır. Köyde toplam 31 hanede, 87 (erkek) nüfus kayıttl olup köyün 1261/1845 y1lı temettüatı 33 080,5 kuruştur. Köy sakini hane reislerinin toplam kazancı ise 29485 kuruştur. Aradaki fark ise komşu Akçaalan Köyü ile Gediz Nahiyesi'nden köyde ortakçılık usulü ziraat yapanların kazancıdır.

Köy adına kayıtlı vergiye değinelim. Öncelikle temettüat defterinin dışında köydeki vergi yükümlüsü hane reislerine ait bir başka vergi kayd1 1258/1842 yılına aittir. "Simav Kazası Ahalisi Vergi Defteri"dir. Bu defterin 26. ve 27. sayfalarında İğdiş Köyü hane reislerinin tek tek vergi kayıtları vardır. Bu kayıtlara göre köy vergi miktarının toplamı 5865 kuruştur. ${ }^{47}$ Temettüat defterinde ise 1260/1844 y1lı virgü-yü mahsusa olarak yer alan miktar ise 6225 kuruştur. ${ }^{48}$ Bu hususta temettüat defterinin mühürlü son sayfasında yer alan diğer bilgiler şöyledir. Aşar bedeli 1260/1844 y1l1 2629 kuruş, 1261/1845 y1lı 2625 kuruştur.

47 BOA. ML. VRD. d. 0827, s. 26-27.

48 BOA. ML. VRD. TMT.d.09203, s. 22. 
Ağnam sayısı da 270 olarak kayıtlıdır. Son olarak köyde 8 kişinin "Hacı" lakaplı olduğunu söyleyelim. Kuşkusuz bu dönem hac farizasının ifası meşakkatli yolculuğu kadar, ağır mali yükümlülük gerektiren bir ibadettir. Vergilerle alakalı 1 krş.' luk "resmi nebat" adı ile kayıtlı çayır/ot vergisi dikkat çeker. Defterde 1260/1844 yılına ait 18 hane için bir kuruşluk nebat/çayır vergisi kaydı vardır.

Tablo: 15 Köy adına kayıtlı vergi miktarları

\begin{tabular}{|c|c|l|l|}
\hline $1258 / 1842$ yılı virgü-yü senevi & $1260 / 1844$ y1lı virgü-yü mahsusa & \multicolumn{2}{|c|}{ Aşar bedeli } \\
\hline \multirow{2}{*}{5865 kuruş } & 6225 kuruş & $\begin{array}{l}1260 / 1844 \\
2629 \text { kuruş }\end{array}$ & $\begin{array}{l}1261 / 1845 \\
2625 \text { kuruş }\end{array}$ \\
\hline
\end{tabular}

\section{Aile Hayat1}

Köy ekonomik yapısına dair detaylı bilgileri paylaştıktan sonra sosyal hayatın temeli olan aile yapısından bahsedelim. Nüfus ve temettüat defterlerindeki bilgiler köyün aile yapısını değerlendirmemize yardımcı olmaktadır. Doğrusu sadece erkek nüfusun yer alması daha teferruatlı bilgi almamıza engel olsa da bazı tespitlerde bulunmamıza mani değildir. Daha önce de belirttiğimiz üzere köyde nüfus defterine göre 78 , temettüat defterine göre ise 87 erkek nüfus yaşamaktadır. Kadın nüfus ile beraber toplamda yaklaşık 200 kişilik bir nüfustan söz edebiliriz. Nüfus defterindeki kayıtlı verileri dikkate aldığımızda tek başına kayıtlı hane reisi sayısı 11'dir. Oğul/oğulları ile beraber yaşayan hane sayısı 17'dir. Bu 17 hanede 20 yaş üzeri olanların evli olduğunu düşündüğümüz 4 oğul sayısı kaydına göre hanelerin çoğunluğunun çekirdek aile yapısını barındırır. Bu noktada toplam hane sayısının \% 71,84'ü çekirdek ailedir. Ayrıca kardeşi, oğul ve torunları ile birlikte yaşayan haneler vardır. Bir hanede üvey evladı kaydı söz konusudur. Detaylı bilgiler aşağıda tabloda yer almaktadır.

Tablo: 16 Köy nüfus defterinde hane reislerinin kayıt șekli

\begin{tabular}{|l|c|}
\hline Kayıt Şekli & Sayı \\
\hline Tek başına kaydedilen hane reisi & 11 \\
\hline Oğlu/Oğulları ile kaydedilen & 17 \\
\hline Kardeşi ile kaydedilen & 1 \\
\hline Üvey oğlu ile kaydedilen & 1 \\
\hline Oğulları ve torunları ile kaydedilen & 1 \\
\hline Oğlu ve torunu ile kaydedilen & 1 \\
\hline
\end{tabular}

Bir hanede yer alan üvey oğlu kaydına dair bilgi vermek yerinde olacaktır. Aynı zamanda köy imamı olan bir no'lu hane reisi Koca Ahmet oğlu Mehmet'in velayetinde baba adı farklı Halil adında 14 yaşında bir genç kayıtlıdır. Diğer oğullarının 25-30 yaşlarında olduğunu dikkate aldığımızda evliliği çok eşlilik olarak yorumlamak biraz zor görünüyor. İlk eşinin vefatı sonrası dul bir kadın ile evlilik yapmış olabilir. Elbette genç delikanlının anne ve babası vefat etmiş de olabilir. Şurası kesin ki, baba evlatlık almış, babaları farklı çocuklar bir arada yaşamaktadır. Yine bu durumu birden fazla evlilik olarak yorumlamakta elbette mümkündür. Kanaatimizce iki seçenekten birisi olmalıdır. Ya çocuğun anne-babasının olmadığı ya da annesi ile beraber geçimlerini idame konusunda sıkıntı yaşadıkları, himaye için evliliğin yapılmış olmasıdır.

Kayıtlarda Hacı Halil 10 no'lu hane reisi olup evinde oğulları ve torunları ile ikamet etmektedir. Bu hanede toplam 10 erkek nüfus kayıtlıdır. Dört oğlundan birisi vefat etmiştir. Vefat eden oğlunun çocukları ile beraber 6 erkek torunu ile aynı haneye kayıtlıdır. Nüfus defterindeki bu bilgiler temettüat defteri ile de örtüşmektedir. Nüfus defterinde 85 yaşında görülen 10 no'lu hane reisi Hacı Halil vefat etmiş olmalı ki, 
kayıtlı değildir. Bu hanede vergi yükümlüsü iki oğlu ile bir torunu yer almaktadır. Tek hanede üç yükümlü görünmektedir.

Nüfus defterlerinde 20 yaş altı erkek nüfus özenle kaydedilmiştir. Sayımın askerliğe elverişli olanları kayıt altına almayı amaçladığı açıktır. Özellikle fiziksel özellikler özenle yazılmış, kişileri tanımlamada dikkat edilmiştir. Hane reisinin oğlu olarak 38 erkek nüfus kayıtlıdır. Tek başına kayıtlı 11 hane mevcuttur. Oğul sayısı en fazla 5'tir. Beş ve dört çocuklu hane birer adettir. Üç çocuklu hane 3, iki çocuklu hane 5, bir çocuklu hane 9'dur. En fazla çocuk sayısı bulunan bir hane içinde 5'dir. Oğul ve torunların bir arada yaşadığ 1 hane sayısı 2'dir. Bu hanelerden birisinde bir oğul ve bir torun vardır. Diğer hane ise köyün en kalabalık hanesi olup üç oğul ile 6 torun aynı hanede kayıtlıdır. Bu kayıt dikkatle incelendiğinde torunlardan ikisinin babasının hane reisinin oğlu olduğu açıkça belirtilmemiştir. Vefatına dair de bir kayıt yoktur. Orduda ya da başka bir yerde olduklarına dair de kayıt düşülmemiştir. Dolayısıyla sadece sağ olanların kaydının alındığını dikkate aldığımızda babaları vefat etmiş olmalıdır.

Tablo: 17 Nüfus defterine göre erkek çocuk sayısı

\begin{tabular}{|c|c|}
\hline \multicolumn{2}{|c|}{ Köydeki erkek çocuk sayısı } \\
\hline Erkek Çocuk Sayısı & Hane Sayıs1 \\
\hline 5 & 1 \\
\hline 4 & 1 \\
\hline 3 & 3 \\
\hline 2 & 5 \\
\hline 1 & 9 \\
\hline Erkek çocuk kaydı olmayan hane & 12 \\
\hline Oğul ve torun bir arada & 2 \\
\hline
\end{tabular}

Nüfus defteri, köyde yaşayan erkek nüfusun net yaşlarını öğrenme imkânı sunmaktadır. Aşağıda yaş dağılım tablosu incelendiğinde köy genç bir nüfusa sahiptir. Köyde yaşayan erkek nüfusun yarısı 20 yaş altıdır. En yaşı bireyler 85 yaşında iki hane reisidir. En küçük yaştakiler ise birer yaşında 6 bebek adı kayitlidir.

Tablo: 18- 1856 yılı köy nüfusuna kayıtlı erkek nüfusun yaş dağılımı

\begin{tabular}{|c|c|c|}
\hline \multicolumn{3}{|c|}{ Köy erkek nüfusun yaş dağılımı } \\
\hline Yaş Aralığ 1 & Sayıs1 & Yüzdelik Dilimi \\
\hline $1-5$ & 14 & 17,94 \\
\hline $6-10$ & 15 & 19,23 \\
\hline $11-15$ & 5 & 6,41 \\
\hline $16-20$ & 4 & 5,12 \\
\hline $21-25$ & 6 & 7,69 \\
\hline $26-30$ & 3 & 3,84 \\
\hline $31-35$ & 3 & 3,84 \\
\hline $36-40$ & 7 & 8,97 \\
\hline $41-45$ & 3 & 3,84 \\
\hline $46-50$ & 5 & 6,41 \\
\hline
\end{tabular}


Journal of Ottoman Civilization Studies

NO. 13 (2021), 1-38

A. Sağlam

\begin{tabular}{|c|c|c|}
\hline $51-55$ & 4 & 5,12 \\
\hline $56-60$ & 3 & 3,84 \\
\hline $61-65$ & 3 & 3,84 \\
\hline $66-70$ & 1 & 1,28 \\
\hline $71-75$ & & \\
\hline $76-80$ & & 2,56 \\
\hline $81-85$ & 2 & 99,84 \\
\hline Toplam & 78 & \\
\hline
\end{tabular}

Tabloda görüldüğü gibi, çocuk olarak kabul edebileceğimiz yaş grubu olan 1-10 yaş grubu 29 kişi olup yüzdelik oran $1 \% 37,17$ 'dir. En kalabalık yaş grubudur. 11-20 yaş grubunda 9 kişi, oranı ise \% 11,53'dür. 21-30 yaş grubunda kayıtlı kişi 9 (\% 11,53), 31-40 yaş grubunda kayitlı 10 (\% 12,81), 41-50 yaş grubunda 8 kişi (\% 10,25), 51-60 yaş grubundaki kişi7 (\% 8,96), 61-70 yaş grubundaki kayıtlı kişi $3(\% 5,12)$, ve 7180 yaş grubunda kayıtlı kimse olmayıp 85 yaşlarındaki 2 hane reisi \% 2,56'lık yüzdelik dilime girmektedir. 


\section{Sonuç}

Makalemizde, Simav kazası İğdiş karyesine ait kayıtların yer aldığı nüfus ve temettüat defterlerindeki bilgilerle, günümüz Kütahya Gediz Yeşilova Köyü’nün 19. Yüzyıl sosyo-ekonomik yapısına dair bir çalışma yaptık. Simav kazası müslim defterinde yer alan kayıtlara göre köyde, 31 hane, 78 erkek nüfus, temettüat defterinde ise erkek nüfus mevcudu 87 olarak kayıtlıdır. Defterde yer almayan kadın nüfus ile beraber toplamda yaklaşık 200 nüfuslu bir köy olduğu anlaşılmaktadır. Ailelerin çoğunluğu çekirdek aile yapısını barındırmaktadır. Bu oran \% 71,84'tür. Oğulları ve torunları ile beraber yaşayanlar daha az görülmektedir. Hane reisleri kendi hane üyeleri ile yaşamaktadır. Sadece köy imamı bir üvey evladı ile kaydedilmiştir. Hiç çocuk kaydı olmayan, sadece hane reisinin adının kayıtlı olduğu hane 12'dir. Bu durum defterde kayıtlı sülale adlarının zamanla kaybolmasının sebebini izah etmektedir.

Köy erkek nüfusun kayıtlı yaşlarına baktığımızda en yaşlısı 85 yaşında iki kişi yer alırken yeni doğan bebek kaydı en fazla birey olarak karşımıza çıkmaktadır. Köy nüfusunda en fazla yaş grubu 29 kişi ile 10 yaş altıdır. Yüzdelik oranı \% 37,17'dir. Ayrıca toplam nüfusun yarısı 20 yaş altından oluşmaktadır (38 kişi $\%$ 48,70). Bu durum köyün genç bir nüfusa sahip olduğunu göstermesi yanında çocukluk evresinden ergenlik evresine geçen nüfus sayısındaki azlığı gösterir. Ölümlerin daha çok çocukluk evresinde olduğu görülür. İncelediğimiz nüfus yoklama kayıtları (1831-1870) bu tezimizi doğrulamaktadır.

Mal varlığ 1 ve gelir tespiti olan temettüat defterine göre köyde 32 hane kayıtlı olup, vergi yükümlüsü 34 hane reisi bulunmaktadır. Kayıtlı 32 haneden 30'u ziraat erbabı olarak kaydedilmiştir. Bir hane de mecnun olarak kayıtlıdır. Mal varlığı olmayıp başkalarının himayesinde Gediz' de hayatını sürdürmektedir. Bir hane de kiralama usulü ziraat yapmaktadır. Bu anlamda vergi yükümlüsü ziraat erbabı olan hane reislerinin 1260/1844 yılı ödedikleri vergi çeşitleri ile bu hususta üretim yaptıkları hububat çeşitleri ve baklagillerden sadece nohut üretimine dair veriler defterde açık bir biçimde yer almaktadır. Yine 1261/1845 yılında vergi yükümlüsü olan mükelleflerin gelirleri ile malvarlıklarının tespiti noktasında ekip biçtikleri tarlalar, sahip oldukları hayvanlar hakkında açık bilgilere ulaştık. Makalemizde kullandığımız bu veriler bize köyün sosyo-ekonomik hayatına dair önemli bilgiler vermektedir.

Köyde her iki defterde 8 kişinin "hacı" lakaplı olması ekonomik açıdan önemli bir göstergedir. Köyün 1258/1842 y1lı virgü-yü senevi 5865 kuruş, 1260/1844 y1lı virgü-yü mahsusa 6225 kuruştur. Köyün 1261/1845 yılı temettüatı ise 33 080,5 kuruştur. Kayıtlı 32 haneden 30'u ziraat erbabı olarak kayıtlıdır. Diğer 2 haneden birisi mecnun, diğeri de kiralama usulü tarla ekip biçmektedir. Ayrıca iki hanede birden fazla vergi yükümlüsü vardır. Bir no'lu hanede 2 kişi, 10 no'lu hanede de 3 kişi arazi ve hayvanatından dolayı gelir vergisi ödemektedir. Köyün geçim kaynakları yerleşim yerinin doğal özelliğine uygun kuru tarım, hayvancılık, arıcılık, kök boyacılığı olarak yer almaktadır. Bunun yanında ustalık, odun taşımacılığı ve satışı gibi işgücü imkânlarının olduğunu söylemek mümkündür. Köylüye ait 54 çift öküz ile 7 çift camus/manda kayıtlıdır. Sabanın kurulması, bakım ve onarımı ustalık gerektirdiği için bu alanda mâhir kimselerin varlığını kabul etmek gerekir.

Köyde 1844 yılında hububat olarak buğday, arpa, nohut, burçak, yulaf üretilmiştir. Üretimin yarıs1 buğdaydır. Sırasıyla buğday \% 48,14, arpa \% 37,74, nohut \% 8,32, burçak \% 2,67, dar1 \% 1,93, yulaf \% 1,18'lik üretim payına sahiptir. Ayrıca yaklaşık olarak buğday üretimi $48600 \mathrm{~kg}$, arpa $33020 \mathrm{~kg}$, nohut 8 960 kg.'dır. Bunun yanında iki hanenin birer evlekten toplam 2 evlek kök boya ektiğine dair kayıt vardır.

Köylünün geçim kaynaklarından önemli bir unsur da hayvanlarıdır. Kayıtlı 32 haneden sadece 5 hanede sabana koşulan çift öküz ya da çift camus kaydı yoktur. Toplam çift öküz kayd 154 iken, çift camus kaydı 7'dir. Kaslarından yararlanılan diğer hayvanların toplamı sırasıyla merkep 37 adet, kısrak 5 adet, katır 5 adet olup dölsüz kısrak, beygir ve tay 3'er adet kayıtlıdır. Kayıtlı binek hayvan sayısı toplamı 56'dır. Sığır cinsi büyükbaş hayvan sayısı toplamı 204 baş iken, küçükbaş hayvan sayısı 1001'dir. 
Köy, tipik bir orta Anadolu köyüdür. Kayıtlar, köyde yaşayanların kendi imkânları ölçüsünde tarım ve hayvancılıkla geçimini sağladığı, bunun yanında binek ve taşıma amaçlı hayvan sayıları dikkate alındığında kayıtlara rastlamasa da köy çevresindeki zengin orman kaynaklarından istifade edildiği anlaşılmaktadır. Diğer orta Anadolu köyleri ile mukayese edildiğinde geçim şartlarının ve imkânlarının daha avantajlı olduğunu söylemek mümkündür. Sabana koşulan çift öküz ve çift camus varlığı dönemin şartlarına göre varlıklı bir yapıyı özetlemektedir.

Köy sakinleri arasında başkalarının yardımı ile geçinen iane, yetim, yaşlı gibi diğer temettüat defterlerinde yer alan kimselere köy kayıtlarında rastlanmaz. Yine ırgat, amelelik, hizmetçi gibi başkalarına iş gören, emeği ile geçinen varlıksız kimselere kayıtlarda yer verilmemiştir. Bu durum köyün ekonomik açıdan o dönem durumunu özetlemektedir. Gelir olarak ödenen vergiler ayrıca bu yorumu destekleyici mahiyettedir. Çok basit bir halk deyimi ile, "kendi yağı ile kavrulan", bir köy hayatı söz konusudur. 


\section{Bibliyografya}

Gediz-Yeşilova Köyü Nüfus Defteri: Hüdavendigar eyaleti Kütahya sancağı Simav kazası müslim nüfus defteri: BOA. NFS. d. 01629. s. 201-203.

Gediz-Yeşilova Köyü Temettüat Defteri: Kütahya Sancağına Tâbi Simav Kazası Kuralarından İğdiş Karyesinin Tahrir-i Temettüat Defteri Sene:1261 Numara; 66: BOA. ML. VRD. TMD. d. No: 09203.

BOA. EV. VKF. 17-45.

BOA. KK. d. 06447-163.

BOA. MAD. d. 262.

BOA. ML. VRD. d. 0827.

BOA. NFS. d.01628

BOA. NFS.d.01627

BOA. TT. 3.

BOA. ML. VRD. TMT. d. 09196.

BOA. ML. VRD. TMT. d. 09213.

BOA. ML. VRD. TMT. d. 09255.

BOA. ML. VRD. TMT. d. 09264.

BOA. ML. VRD. TMT. d. 09251.

BOA. ML. VRD. TMT. d. 7905.

BOA. ML. VRD. TMT. d. 7921.

Basılı Eserler

Adıyeke, N. (2000), "Temettuat Sayımları ve Bu Sayımları Düzenleyen Nizamname Örnekleri”, Ankara Ünüversitesi, Osmanlı Tarihi Araştırma ve Uygulama Merkezi Dergisi, OTAM, SAYI 11, 2000, s. 769-825.

Baykara, T. (1996), "Selçuklular Devrinde İğdişlik ve Kurumu”, Belleten, LX, 229, s. 681-693.

Göksal, H. (2013), 19. Yüzyıl Ortalarında Gediz’in Sosyal ve Ekonomik Tarihi, Gediz Belediyesi Kültür Yayınlar1, 2013.

Gümüşcü, O. (2010), Tarihi Coğrafya, Yeditepe Yayınevi, İstanbul.

Güran, T. (2000), “XIX. Yüzyıl Temettüat Tahrirleri”, Osmanlı Devletinde Bilgi İstatistik, (H. İnalcık, Ş. Pamuk Der.), Ankara, s. 73-94.

Hasan b. Abdülmü'min el-Hôyî’nin Kaleminden Selçuklu İnşâ Sanatı (Haz. Cevdet Yakupoğlu-Namiq Musal1), Türk Tarih Kurumu Yayınları, Ankara 2018.

İnalc1k, H. (1996), Osmanlı İmparatorluğu: Toplum ve Ekonomi, Eren Yayınc1lık, İstanbul.

Karal, E. Z. (1943), Osmanlı İmparatorluğunda İlk Nüfus Sayımı 1831, T.C Başbakanlık Devlet İstatistik Enstitüsü Yayınları, Ankara, s. 8-11.

Kaşgarlı Mahmud, Dîvânü lugâti’t-Türk. 
Kütükoğlu, M. S. (1995), “Osmanlı Sosyal ve İktisadî Tarihi Kaynaklarından Temettüât Defterleri”, Belleten, LIX, s. 395.

Makrîzî, (1994), Kitâbü's-Sülûk li-Ma'rifeti Düveli'l-Mülûk, I-IV, (Thk. Muhammed Mustafa Ziyade-Said Abdülfettah Âşûr), Kahire.

Sümer, F. (2000), “İğdiş”, Türkiye Diyanet Vakfi İslâm Ansiklopedisi, c. XXI, s. 524-525.

Sümer, F. (1985), "Selçuklu Tarihinde İğdişler”, Türk Dünyası Araştırmaları, Sayı:35, s. 9-23.

Şen, S. (2007), “Ĭğdiş Sözcüğü Nereden Geliyor?”, İlmî Araştırmalar, Sayı: 23, s. 123-190.

Şemseddîn eş-Şücâî, (1997), Târîhu'-l-Meliki'n-En-Nâsırî Muhammed bin Kalavun es-Sâlihî ve Evlâdihî, (Thk. Barbara Schafer), Wiesbaden.

Turan, O. (1958), Türkiye Selçukluları Hakkında Resmi Vesikalar, Ankara.

Uçar, E. (2019), “Kutadgu Bilig Dizinindeki Bir Kelime Hakkında VIII: İğdiş ve İğdişçi Sözcüğü”, Korkut Ata Türkiyat, Uluslararası Türk Dili ve Edebiyatı Araştırmaları Degisi, Cilt:1, Sayı: 1, Aralık, s. 1118.

Cevdet Yakupoğlu, "Aslanapa Yöresinde Türk İskânının Belgeleri: Yer ve Şahıs Adları (XII-XVI. Yüzylllar)", Uluslararast Batı Anadolu Beylikleri Tarih, Kültür ve Medeniyet Sempozyumu-III Germiyanoğulları Beyliği 8-10 Mayıs 2014, Bildiriler Kitabı, Yayına Hazırlayanlar: Mehmet ErsanMehmet Şeker, Türk Tarih Kurumu, Ankara 2017, s.423-472.

Yusuf Hâs Hacib, Kutadgu Bilig, (nşr. Reşit Rahmeti Arat), Ankara 1947.

Yiğit, İ.(2011). "XIX. Yüzyıl Tarihi Coğrafya Çalışmaları İçin Önemli Bir Kaynak: Temettüat Defterleri", Türk Coğrafya Kurumunun 70. Kuruluş Y1lı Anısına: "UKCK-2011" Bildirileri, 7-10 Eylül 2011 İstanbul.

Yiğit, İ.-Kocabıyık, M. (2016), "XIX. Yüzyıl Anadolu'sunda Tarımsal Yapı”, 2016 Hoca Ahmet Yesevi Yılı Anısına Uluslararası Türk Dünyası Eğitim Bilimleri ve Sosyal Bilimler Kongresi, s. 227-239.

370 Numaralı Muhâsebe-i Vilâyet-i Rûm-İli Defteri (937/1530), Kütahya, Kara-hisar-i Sâhib, Sultan-önü, Hamîd ve Ankara Livâları, Ankara 1993.

Tezler

Kaplan, A. (2005), "19. Yüzyılda Gediz Nahiye'sinin Sosyo-Ekonomik Yapısı”, İstanbul Üniversitesi, Sosyal Bilimler Enstitüsü İktisat Tarihi Anabilim Dalı, İstanbul 2005.

Gürsoy, F.T. (2011), "XVI-XIX. Yüzyıllarda Gediz'de Toplumsal Hayat”, Uşak Üniversitesi, Sosyal Bilimler Enstitüsü Sosyal Bilimler Anabilim Dalı, Uşak 2011. 
Ek: 1 Google Earth üzerinde köyün yerleşim merkezi ile çevresindeki ekili alanları gösteren uydu görüntüsü.

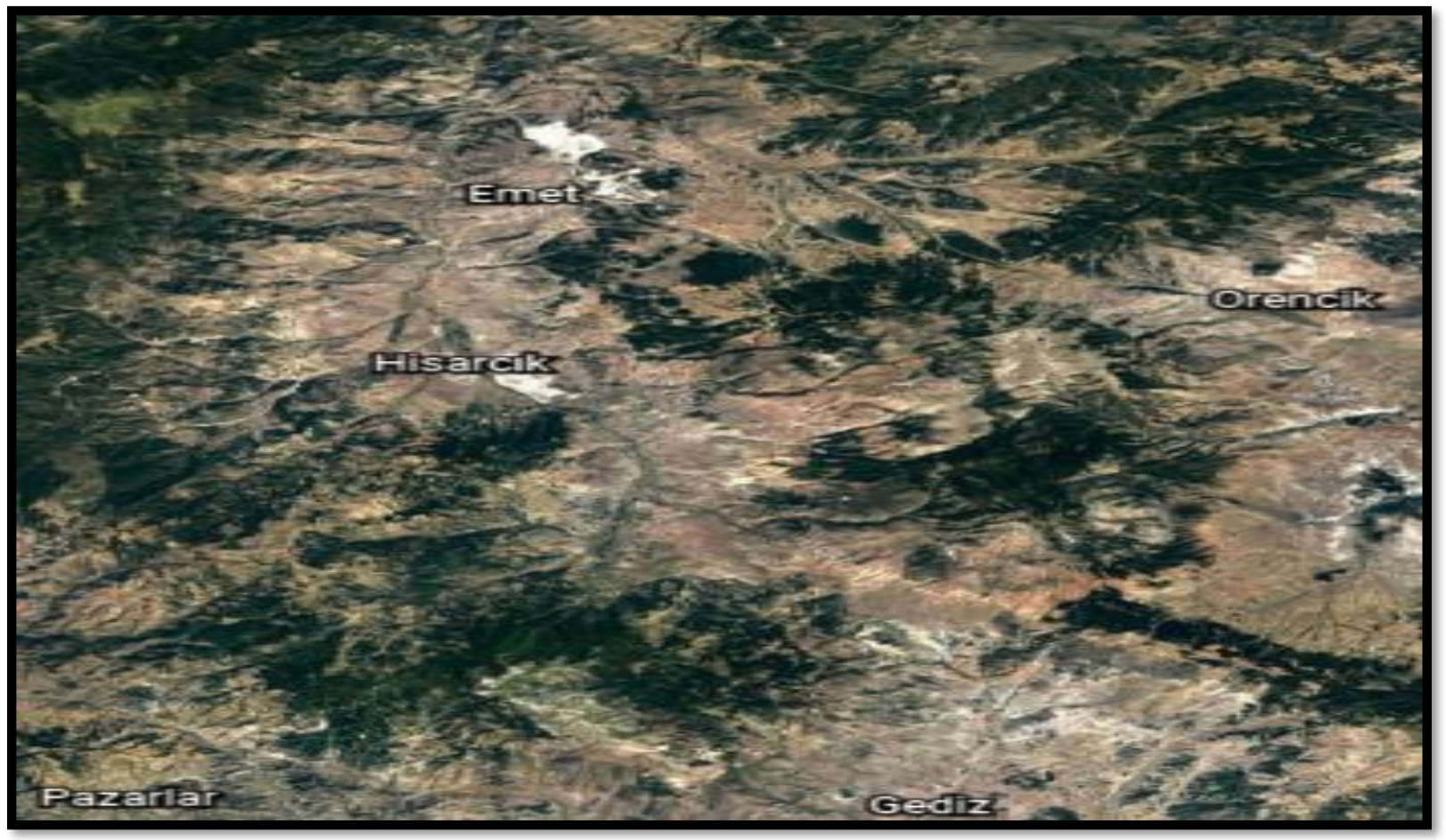

Ek:2 Köy; Gediz-Hisarcık-Emet güzergâhında güney-kuzeybatı istikametinde uzanan geniş bir vadi üzerinde yer alır. Güzergâhın Google Earth üzerinden görünümü

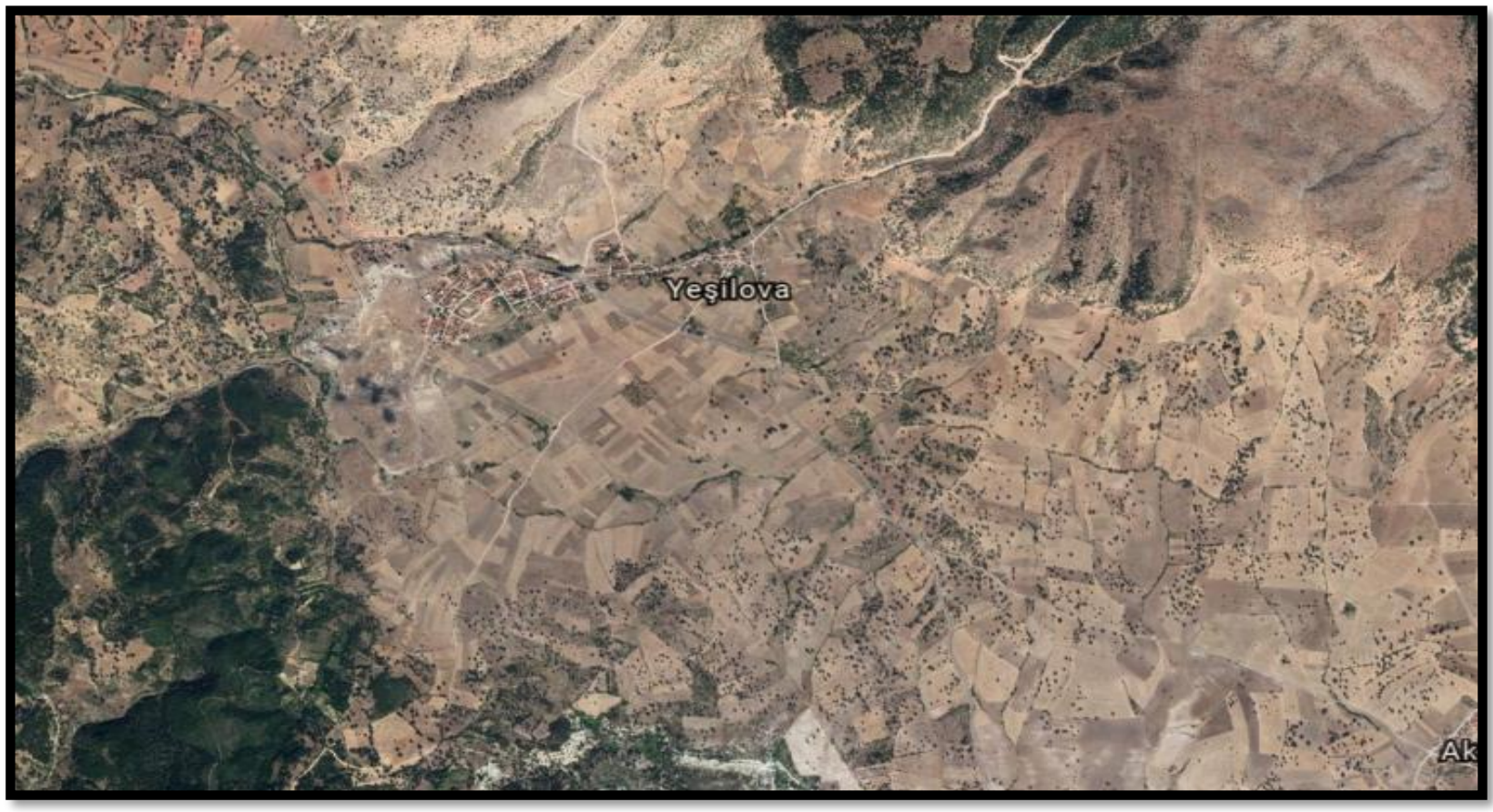


Journal of Ottoman Civilization Studies

NO. 13 (2021), 1-38

A. Sağlam

Ek: 3 Köy ve çevre köy merkezlerinin Google Earth üzerinden görünümü.

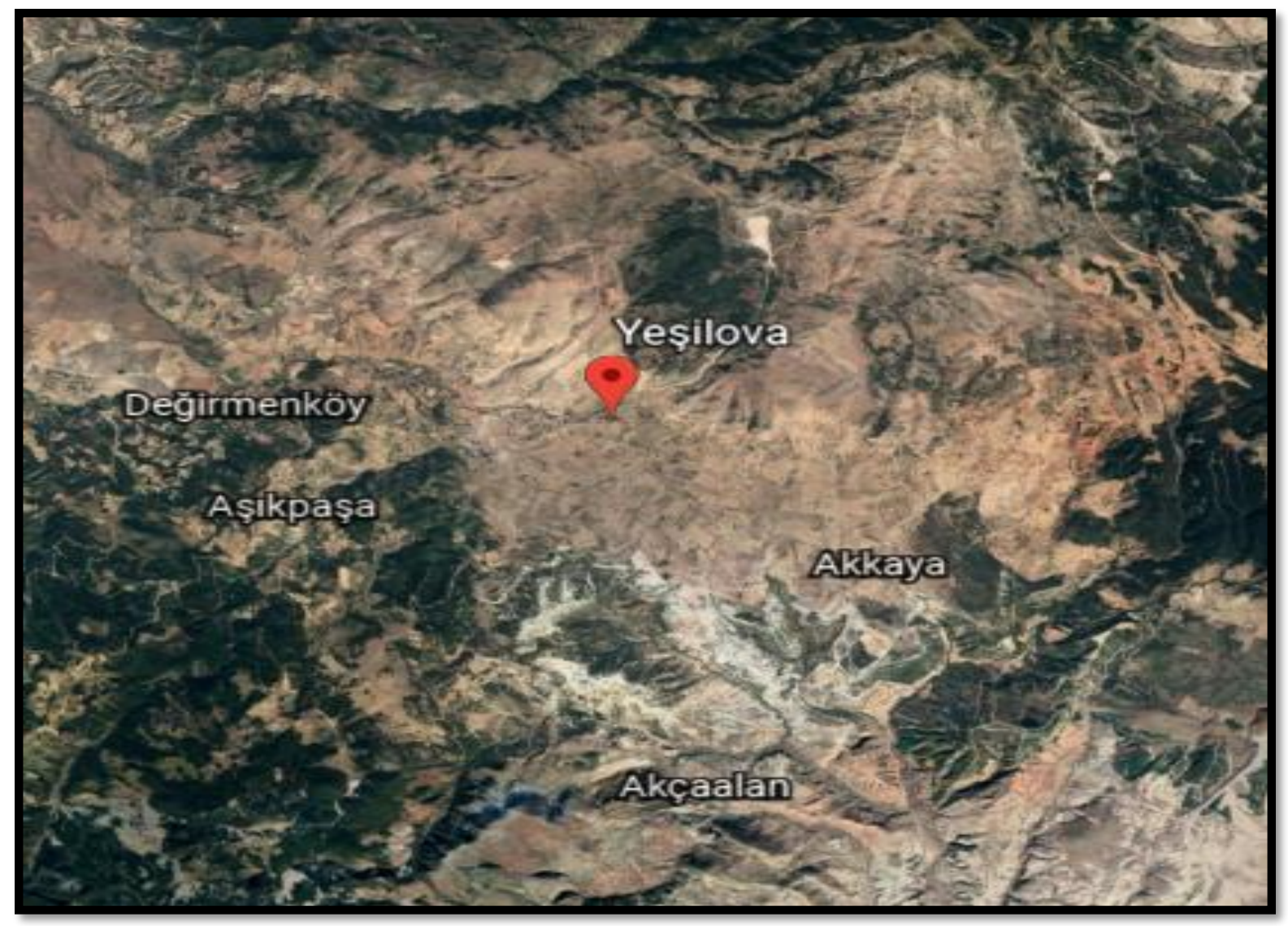


Journal of Ottoman Civilization Studies

NO. 13 (2021), 1-38

Ek: 4 Köy temettüat defterinin ilk sayfası

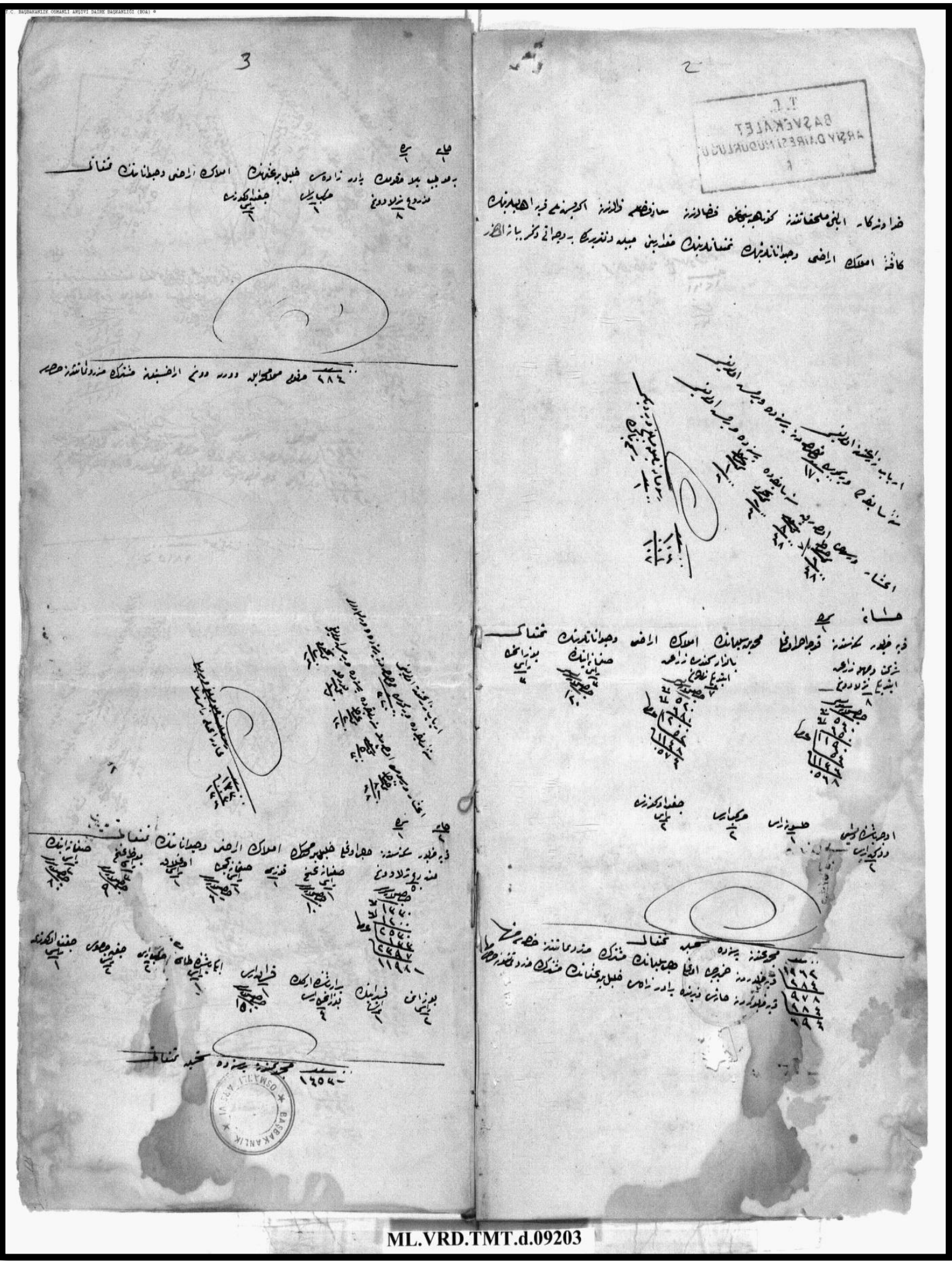


Journal of Ottoman Civilization Studies

NO. 13 (2021), 1-38

Ek:5 Köy temettüat defterinden bir başka sayfa.

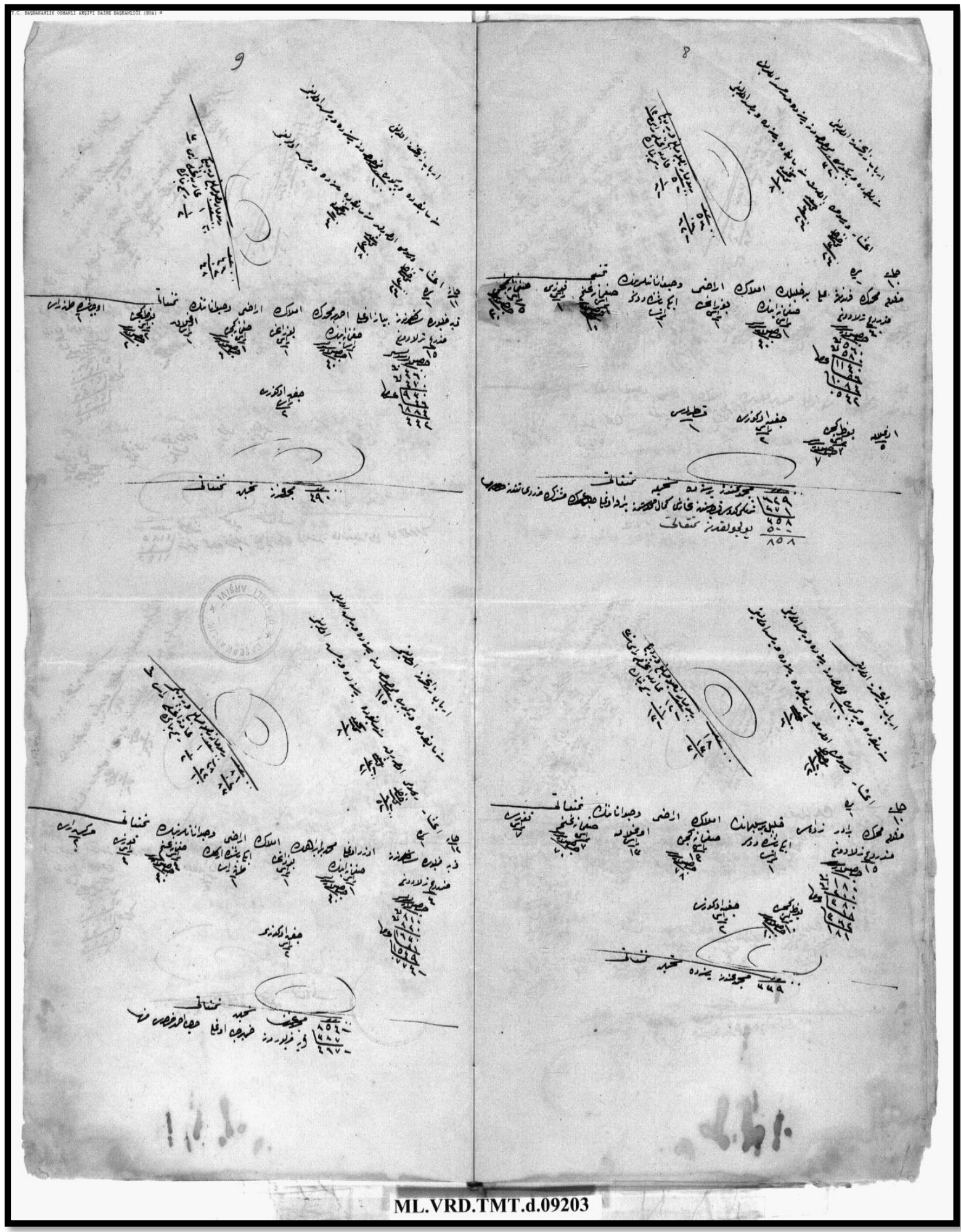


Journal of Ottoman Civilization Studies

NO. 13 (2021), 1-38

Ek: 6 Köy temettüat defterinin mühürlü son sayfası.

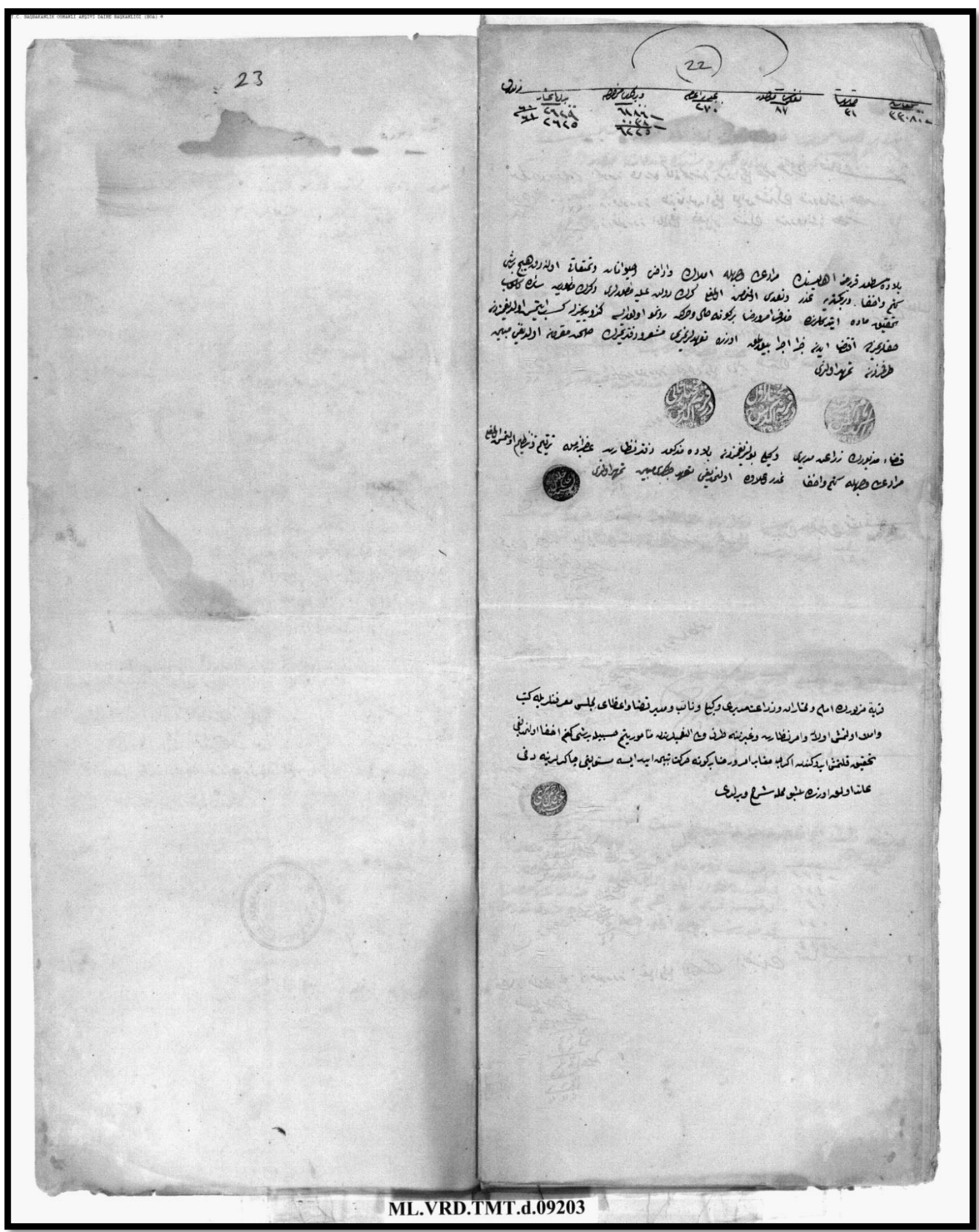


Journal of Ottoman Civilization Studies

NO. 13 (2021), 1-38

Ek: 7 Köy nüfus defterinin ilk sayfası

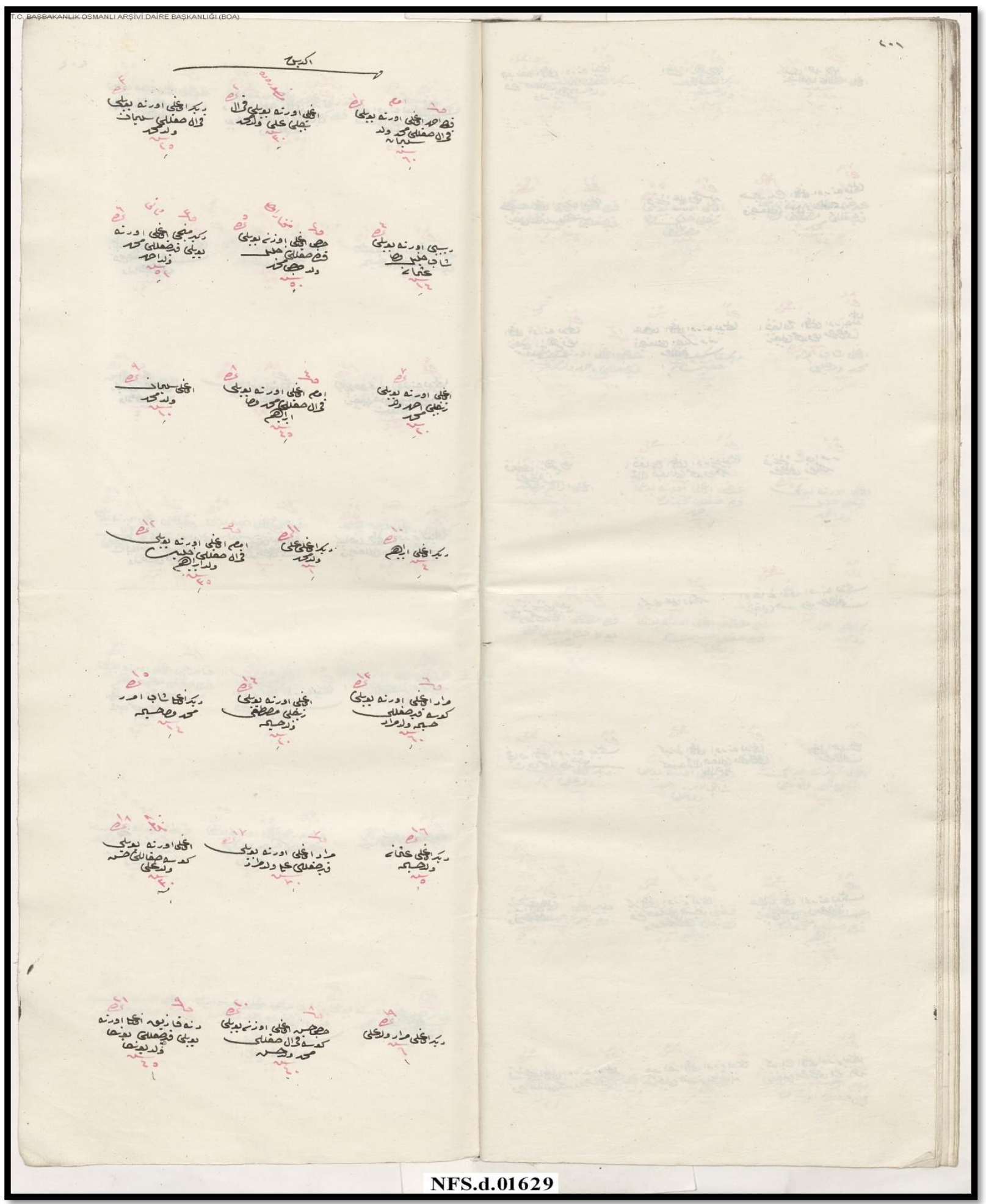

